\title{
Gods, birds, and trees
}

\section{Variation in illustrated Javanese pawukon manuscripts}

\author{
DICK VAN DER MEIJ
}

\begin{abstract}
$^{1}$
Many libraries in the world own illustrated manuscripts containing calendrical divination based on the Javanese 30 seven-day wuku cycle. Although the contents of these pawukon manuscript have been studied, the illustrations they often contain have almost been ignored. Apart from stating that these illustrations usually depict the gods, trees, buildings, and birds associated with each individual wuku, the variety among these illustrations has escaped scholars so far. Variation is found at many levels such as the general lay-out of the illustrations, the depiction of the various gods, trees, et cetera but also with reference to the position of the illustrations and the accompanying texts that explain the characteristics and divination possibilities of each wuku. This article intends to offer a start into the study of these illustrations by offering examples of these illustrations and the connections that may have existed between the makers of these illustrated manuscripts.
\end{abstract}

KEYWORDS

Pawukon; Javanese manuscripts; Javanese illustrations; divination; Java; Indonesia.

The Javanese calendar contains a constantly recurring cycle of thirty wukus of seven days. Each wuku bears the name of a character that features in the myth of Dewi Sinta and King Watu Gunung, although Kumar argues that perhaps the myth was created after the wuku cycle came into use. ${ }^{2}$ In any case, the wukus

1 Many thanks to Peter Worsley who kindly commented on an earlier draft of this article, Genie Yoo for her excellent suggesions for the final version and Rosemary Robson and Milly Wagemann for their help with my English.

2 See Kumar 2009/2011, 2018; Miyazaki 2018.

DICK VAN DER MEIJ was born 11 December 1956 in Lisse in the Netherlands. He studied Indonesian Languages and Cultures at Leiden University and defended his PhD in 2002. At present he is Academic Advisor and Liaison Officer for the program DREAMSEA, Digital Repository of Endangered and Affected Manuscripts in Southeast Asia. His main publication is: Indonesian manuscripts from the Islands of Java, Madura, Bali and Lombok (Leiden: Brill, 2017). Dick van der Mei may be contacted at: dickvandermeij2012@gmail.com.

(C) 2019 Faculty of Humanities, Universitas Indonesia

DICK VAN DER MEIJ | DOI: 10.17510/wacana.v20i1.729. 
are named successively after Sinta (King Watu Gunung's first wife), Landep (Sinta's sister and the king's second wife), the king and Sinta's twenty-seven sons (thirteen twins plus one), and lastly King Watu Gunung himself. ${ }^{3}$ The complete list of the names of the 30 wukus is as follows: ${ }^{4}$

\begin{tabular}{|l|l|l|l|l|l|l|l|l|l|}
\hline 1 & Sinta & 7 & Wariga alit & 13 & Langkir & 19 & Tambir & 25 & Bala \\
\hline 2 & Landep & 8 & $\begin{array}{l}\text { Wariga } \\
\text { gung }\end{array}$ & 14 & $\begin{array}{l}\text { Mondha- } \\
\text { siya }\end{array}$ & 20 & $\begin{array}{l}\text { Mendang- } \\
\text { kungan }\end{array}$ & 26 & Wugu \\
\hline 3 & Wukir & 9 & $\begin{array}{l}\text { Julung } \\
\text { Wangi }\end{array}$ & 15 & $\begin{array}{l}\text { Julung } \\
\text { Pujud }\end{array}$ & 21 & Maktal & 27 & Wayang \\
\hline 4 & Kurantil & 10 & Sungsang & 16 & Pahang & 22 & Wuye & 28 & Kulawu \\
\hline 5 & Tolu & 11 & Galungan & 17 & Kuruwelut & 23 & Manail & 29 & Dukut \\
\hline 6 & Gumbreg & 12 & Kuningan & 18 & Marakeh & 24 & $\begin{array}{l}\text { Prang- } \\
\text { bakat }\end{array}$ & 30 & $\begin{array}{l}\text { Watu } \\
\text { Gunung }\end{array}$ \\
\hline
\end{tabular}

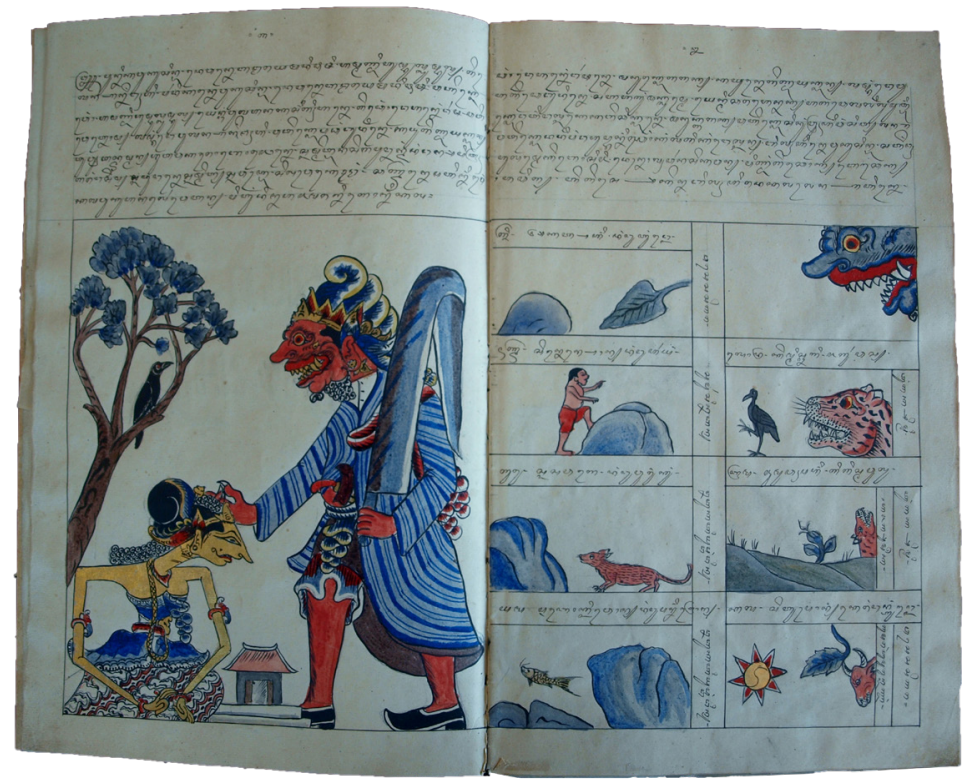

Illustration 1. Wuku Sinta. (Leiden University Libraries, Cod.Or. 6405).

Each wuku is associated with a specific god (dewa, called Bathara, Hyang or Sang Hyang plus the name of the god) or goddess (dewi, called Bathari), bird (manuk, peksi), tree (kayu), building (gedhong), flag (umbul-umbul like the deity Yamadipati carries in his left hand in Illustration 1), water vessel (bokor toya), and weapon (senjata), all of which possess their own distinct characteristics

3 Curiously, the person personifying Wuku Wayang in Wilpert 1980 is a woman rather than a man.

4 Please note that the spelling of the names of these wukus can differ from one manuscript to another which might point to different pronunciations and thus possibly to the different regions in which they were produced. 
which are deemed to be reflected in a person born in a specific wuku. ${ }^{5}$ In other words, if one knows the wuku in which a person is born, his or her character is known as well. The wuku descriptions also include information about the particular dangers that might befall an individual and the misfortunes he may experience in life and what should be done to avoid them. The text and translation in Illustration 1 from Cod.Or. 6405 exemplify what the text of one pawukon manuscript says about the first wuku, Sinta. ${ }^{6}$ In this particular manuscript, the text runs at the top over the two opposite pages above the illustrations. The kind of pawukon illustrations I discuss in this article concern those that are presented on the left page in this manuscript. The illustrations on the right page concern other divinatory elements which I do not discuss in detail in this article.

Illustration 1 above is the Wuku Sinta. Sinta's god is Bathara Yamadipati who carries an umbul-umbul flag on his shoulder. Her building stands in front (between Sinta and Yamadipati). Her bird is the crow. Her tree is the Gendhayakan. Her symbol is the half-moon (not depicted in the illustration). The meaning of Wuku Sinta, with Bathara Yamadipati for god, is character: magnanimous and forgiving, conversation: easy, causing the mistakes of others to be forgotten. The carrying of an umbul-umbul flag indicates when in service, a holder of high office. The building in front: character: showing one's kindness openly. Bird: crow: character: gifted with inspired wisdom, and retaining one's youthfulness for a long time. Symbol: half-moon: character: open-hearted. Tree: Gendhayakan: character: a shelter for people in distress. Wuku Sinta's misfortune: in mid-life: unhappy in marriage, or both partners equally unwise. [To counterbalance this misfortune] arrange a ceremonial communal meal (selamatan) for them at which you serve the sacred food of one bowl with 3.5-kilogram cooked rice ${ }^{7}$ and meat from one buffalo prepared in four ways: as pindhang (a kind of soup), gecok (a minced meat dish), becek (meat stew), and garang asem (meat cooked with spices and vegetables). The Arabic prayer to be recited is the slamet prayer. The salawat fee (for the saying of the prayer) should be 25 half-cent coins (in cash). The prophetic aphorism (concerning the end of life) is: the death of a noble man, which means: meeting disaster through negligence. The Kala (evil demon) of the wuku lurks in the north-east. One should not move in Kala's direction for seven days (after the communal meal has been held). ${ }^{8}$

For the characters of these wukus see Kumar 1996, 2018.

Pigeaud 1970: 44-45 with some changes made by the author.

7 The only reference I could find about the amount of rice to be served is on https:/ / www. primbon.net/2014/08/wuku-sinta-batara-yama.html, accessed on 28-11-2018.

8 Punika wuku Sinta, dewane Bathara Yama Dipati, amandhi umbul-umbul, gedonge aneng ngarsane, manuke Gagak, kayune Gendhayakan, lambange Wulan Anengahi, pardikane wuku Sinta, dewane Bathara Yama Dipati, wateke agedhe budine, sarta agung maklume, yen micara enak agawe lali luput ing wong, amandhi umbul-umbul yen ngawula ana kasinggihane, gedhonge aneng ngarsa, wateke ngatingalake kabecikane, manuk Gagak wateke sinung wruh ing wangsit, lan awet nom, lambange wulan anengahi, wateke padhang budine, kayu Gendhayakan wateke dadi pangahuban ing wong kang lagi kangelan, bilahine wuku Sinta, satengah tuwuh tandraman utawa karo bojone, slametana sega pulen dangdangan sapitrah, ulame kebo siji, den-olah warna sekawan, pindhang gecok becek garang 


\section{PAWUKON MANUSCRIPTS}

A number of libraries throughout the world preserve illustrated Javanese pawukon manuscripts containing divinatory calendars based on the Javanese cycle of thirty wukus of seven days. ${ }^{9}$ For this article, I have concentrated mainly on manuscripts in Leiden University Libraries ${ }^{10}$ but I have also consulted digitized pawukon manuscripts in the collections of the British Library (MSS Jav 36, London Add MS 12338, and BL Or 15932) ${ }^{11}$ and the Staatsbibliothek zu Berlin (Berlin Ms. or. oct. $\left.4036^{12}\right) \cdot{ }^{13}$

It is impossible to tell what it actually contains just from the title (or given title $)^{14}$ of a pawukon manuscript. It is good to bear in mind that the information in different pawukon manuscripts is not necessarily exactly the same. Some pawukons are written in prose while others were composed in Javanese poetic metres called tembang gedhe and tembang macapat. ${ }^{15}$ The sequence of the information given for each wuku might also differ in the same manuscript and from one manuscript to another. Pawukons have been widely consulted in Java in the past and are probably still used today as they can easily be found on the Internet. ${ }^{16}$

\section{ILLUSTRATED PAWUKONS}

A number of pawukon manuscripts are illustrated and contain depictions of the gods, birds, trees, buildings, umbul-umbul flags, water vessels, and weapons. Sometimes, they do not include pictures of all these elements, even though the accompanying texts state all of them and the characteristics they represent. In other cases, they illustrate all the elements but do not mention all of them

asem dungane slamet slawate, selawe ketheng, candrane patining wong awig, tegese kena bilahi rada kalalen atine, Kala wuku ana ler wetan, pitung dina aja marani gon ing Kala.

9 National Library of Indonesia in Jakarta, the University of Indonesia in Depok, the Royal Palaces of Yogyakarta and Surakarta in Central Java, the Museum Sonobudoyo in Yogyakarta, Leiden University Libraries in the Netherlands, the British Library in London, and the Staatsbibliothek zu Berlin in Germany, to name some of them.

10 I have done so because I happened to be in Leiden when I began writing this contribution and fortunately the Library allows these manuscripts to be photographed and the photos to be used in publications.

11 See https://blogs.bl.uk/asian-and-african/javanese.html?_ga=2.217245270. 1909713202.1540896396-1921230104.1521660923. Dr Annabel Teh Gallop kindly allowed me to use the images she sent me of the manuscripts from London I use here.

12 Seehttp://orient-digital.staatsbibliothek-berlin.de/receive/SBBMSBook_islamhs_00013724.

Dr Thoralf Hanstein kindly sent me the links to digitized versions of manuscripts in the Berlin collections.

13 A list of the manuscripts used is found below at the end of the article. Dr Annabel Teh Gallop of the British Library and Dr Thoralf Hanstein from Berlin kindly gave me permission to use some of the pictures of these manuscripts for this article.

14 Many Javanese manuscripts do not have a title and titles are usually given to manuscripts by cataloguers or scholars who study the manuscripts.

15 On these metres, see, for instance, Arps $(1986,1992)$ and Van der Meij (2017: 243-293).

16 For instance: http:/ / tedjatirta.blogspot.com/2010/10/pawukon-lengkap.html, accessed on 28-11-2018. According to Kumar (2018), the wuku calendar is no longer used in Java but, in view of the large number of websites about wukus and divination tables which offer the wukus for sometimes up to 3,000 years, I wonder if this is really true. 
in the accompanying text as in the case with MSS Jav 36 from the British Library which only mentions the gods, birds, and trees. Other manuscripts also contain information and illustrations that point to individuals' character traits based on the specific combinations of the days of the five- and sevenday weeks (pancawara ${ }^{17}$ and saptawara) and of the six- and nine-day weeks (sadwara and sangawara) on which they are born in combination with the wuku and other divinatory elements from the Javanese calendar. ${ }^{18}$ This is the case in the illustrations in Cod.Or. 6405, Cod.Or. 11.650, and Cod.Or. 12.332. Interestingly, I have found no sources which explain why the specific god, bird, tree, and so forth are attributed to any particular wuku and so the link between the $w u k u$ and these elements remains an enigma. It is also a mystery to me why only these elements and not also others are used to indicate a person's character and circumstances in life or why indeed these elements were chosen to begin with.

Although the contents of these pawukon manuscripts have been studied, ${ }^{19}$ the illustrations they contain have largely been ignored although some facsimiles were published in the past. ${ }^{20}$ Apart from stating that these illustrations usually depict the elements associated with each individual wuku, so far, the particulars of and differences between these illustrations have escaped scholarly attention. Pawukons exhibit variations on many levels: the general lay-out of the illustrations, the number of elements depicted in the illustrations, the ways the various gods, trees and such are portrayed and positioned relative to each other, and the mise-en-page of the illustrations and the accompanying texts which state each $w u k u$ 's characteristics.

\section{VARIATION IN WUKUS}

Before considering the illustrations in the ten pawukon manuscripts consulted here, ${ }^{21}$ a look at the wukus themselves, their names and their corresponding gods and so forth as found in the manuscripts is essential. It appears that there is no consistency about which god rules over which wuku or indeed about the trees, birds, and so forth. The fact that no consensus exists in these matters probably points to differences in the ways the texts and illustrations were compiled over time, in different places and probably in different social contexts. The fact that, in general, many Javanese manuscripts, and also many of the ten used here, do not have a colophon which informs us when and where they were written and

17 The five- and seven-day weeks are the most important. The names of the five days in the pancawara or pasaran week are Umanis/Legi, Paing, Pon, Wage, and Kliwon. The days of the saptawara in modern Javanese are Ahad/Minggu, Senin, Slasa, Rebo, Kemis, Jumuwah/Jumat, Setu. Other names for the saptawara are Redite, Soma, Anggara, Buda, Wraspati, Sukra, and Saniscara. For more information on the Javanese calendar see Ricklefs 1978; Kumar 1996, 2009/2011, 2018; Van der Meij 2017, Chapter 6.

18 For more information on the Javanese calendar see Van der Meij 2017, Chapter 6.

19 See for instance Koji Miyazaki 2018 for a late example.

$20 \quad$ See Clara B. Wilpert 1980; Djoko Mulyono 1993.

21 A list of the manuscripts consulted for this article and more information about them is included at the end. 
by whom or tell us about their origins in other ways makes it difficult to draw any definite conclusions on these issues. This is a pity because the historical background of manuscripts can teach us much about these matters and, knowing that a manuscript was, for example, commissioned may be very important as it would probably not have had the role or the use it once had in its original setting and thus may differ from manuscripts that were actually used..$^{22}$

There are some manuscripts of which we know when they were written. The British Library manuscript MSS Jav 36 has a colophon stating that it is from AD 1738 and used to be part of the collection of Colonel Collin Mackenzie (1754-1821) before it found its final destination in the British Library. ${ }^{23}$ The cover of another manuscript, Cod.Or. 2230, states that it was written by Pangeran Arya Adikusuma. As it was part of the "Collectie Rijksinstelling" which went to Leiden in 1878, it must be older than that year. Manuscript Add MS 12338 in the British Library was written in AD 1807 and used to be part of the Crawfurd Collection. The British Library manuscript BL Or 15932 used to belong to Kyai Suradimanggala, Bupati Sepuh of Demak, in "Bagor" (Bogor) and was written in AD 1814-1815.

Four of the six manuscripts in our sample about which we have only external information were purchased by or given to G.A.J. Hazeu (Cod.Or. 6405 in 1900 and Cod.Or. 6446 in 1907) and H. Kraemer (Cod.Or. 12.233 in 1930 and Cod.Or. 11.650 in 1931). One was made for W. Bernasco as a memento when he left Indonesia and which he donated to the KITLV in Leiden in 1969 (D Or. 410). ${ }^{24}$ Turning to manuscript Berlin Ms. or. oct. 4036 we can assume it was written before the Second World War at the behest of Mr Paardekoper, one-time Resident of Blora, Central Java. We can probably conclude this as the script of Berlin Ms. or. oct. 3990, 3995, and 3996, which were commissioned by Paardekoper, is the same as that in Berlin Ms. or. oct. 4036, although this is, of course, not 100 per cent proof. ${ }^{25}$ Even though we cannot establish the exact date of production of these manuscripts, they all clearly date from the early nineteenth to the first half of the twentieth century, thus from the modern period.

So far, in the study of the materiality of Javanese manuscripts, not much progress has been made in the investigation of such things as ink and paint, bindings, paper, watermarks, and so forth. Under these circumstances, at present it is hazardous to draw any conclusive conclusions about these matters with regard to the manuscripts under discussion. Nor do we have enough palaeographical information about the way the Javanese script was executed in different periods and places to help to make decisions about the origins of these manuscripts.

22 For more about commissioned manuscripts and their differences with manuscripts from the field for textual and manuscript study see Van der Meij 2017: 99-104. See also Gallop 2017 for a discussion of commissioned manuscripts in Malay.

23 On Mackenzie and Javanese manuscripts see, for instance, Weatherbee 1978 and Gallop 2019.

24 See Van der Meij 2017: 408-410.

25 For illustrations of these manuscripts see Pudjiastuti and Hanstein 2016: 200, 205, and 249. 
It is also impossible to say with certainty if any of these manuscripts were ever in fact used by owners and practitioners. It is, for example, uncertain whether the four manuscripts Hazeu and Kraemer collected were produced for them at their request and later given to or purchased by them or were made for users. Pigeaud's statement about Cod.Or. 12.233, "It seems likely that the book was written for the use of a lady belonging to the royal family of Surakarta, about the middle of the 19th century", is interesting but he offers no proof that this was really the case. ${ }^{26}$ The two clearly commissioned manuscripts (D Or. 410 and Berlin Ms. or. oct. 4036) were in all likelihood never used.

The table at the end of this article shows the differences in three elements of the ten manuscripts under discussion: the gods who rule the wukus, their trees, and their birds. There is also variation in the other elements but in this discussion, I limit myself mostly but not exclusively to these three because they are apparently the most important of the wuku elements. They are mentioned and portrayed in all the manuscripts (except Cod.Or. 11.650) and there are striking differences between them. The table also reveals that many of the gods and other elements mentioned in the first manuscript, Cod.Or. 2230, which is thought to come from Palembang or West Java, differ the most from all the other manuscripts, closely followed by BL Or 15932. We can draw few conclusions about this matter in the case of MSS Jav 36 since only sixteen pages with illustrations have survived and so we do not know what was on the missing fourteen pages. Perhaps regional and temporal variation is in evidence and should be taken into account when we study these manuscripts. In order to illustrate some of the variety among the manuscripts, I have chosen the Wukus Galungan (wuku 11), Mondhasiya (wuku 14), and Marakeh (wuku 18). Illustrations from these three wukus are presented in Illustrations 7-19. Illustration 20 shows some of the variety of the depictions of the natural world while illustrations 21-26 have been included to show the variety with which the gods Antaboga and Nagagini, Singajalma, and Gana have been portrayed in various manuscripts. We begin by taking a look at the so-called wayang style used in most manuscripts.

\section{WAYANG STYLE}

The oldest manuscript in our sample is MSS Jav 36 (Illustration 2) which depicts the gods in a style reminiscent of the wayang beber, the Javanese theatre play that uses scrolls with wayang-style illustrations. The scroll is unwound as the narrator tells the story depicted on it. The manuscript is unique in this respect. Especially the way the faces of the gods are depicted reminds us of wayang beber, but the depictions of their bodies do not. The depiction of the other elements does not resemble the wayang beber style and the same can be said of the composition of the elements in relation to each other. 


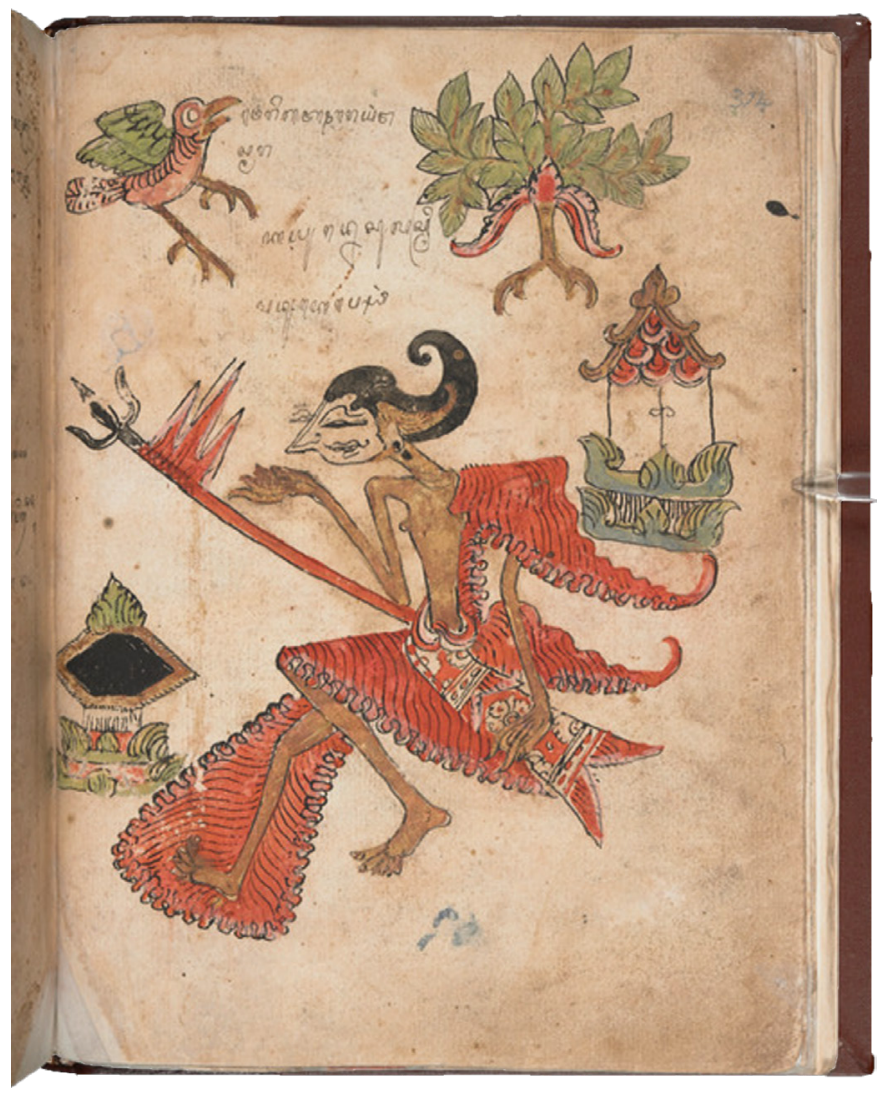

Illustration 2. Wuku Wariga with god Asmara (detail). (British Library, MSS Jav 36).

With the exceptions of Cod.Or. 11.650 and BL Or 15932, the first thing we notice in the other manuscripts is that the depiction of the gods and the characters after whom they are named - but not the trees, birds, and so on - are in what is commonly called the "wayang" style, the style of the puppets of the Javanese shadow play. ${ }^{27}$ The iconography of the human and divine characters used in the manuscripts sometimes clearly reflects that of existing wayang puppets, but in other cases the style is freer and resembles that of the wayang but does not reflect any existing wayang puppets. In some manuscripts there is a mixture of different wayang styles, those of the wayang purwa (with stories from the Mahäbhärata and Rāmāyana) and wayang gedhog (with stories from the Damarwulan) but while the style looks like that of the wayang purwa and wayang gedhog puppets, the figures as they are could not possibly be used for wayang performances. We only need to look at the faces of these figures and their bodily postures to see that they are different from real puppets. In real wayang, the puppets of each individual character remain largely the same 
and the colours, body postures, and ways of dress express the characters of the puppets and their states of mind with minor changes (wanda) but, looking at the illustrations, this does not seem to be the case in pawukons. There is also the danger we might make wrong interpretations of characters in pawukon illustrations when we base ourselves on the way wayang puppets portray character traits. The differences between the depictions of Prabu Watu Gunung below are illustrative.

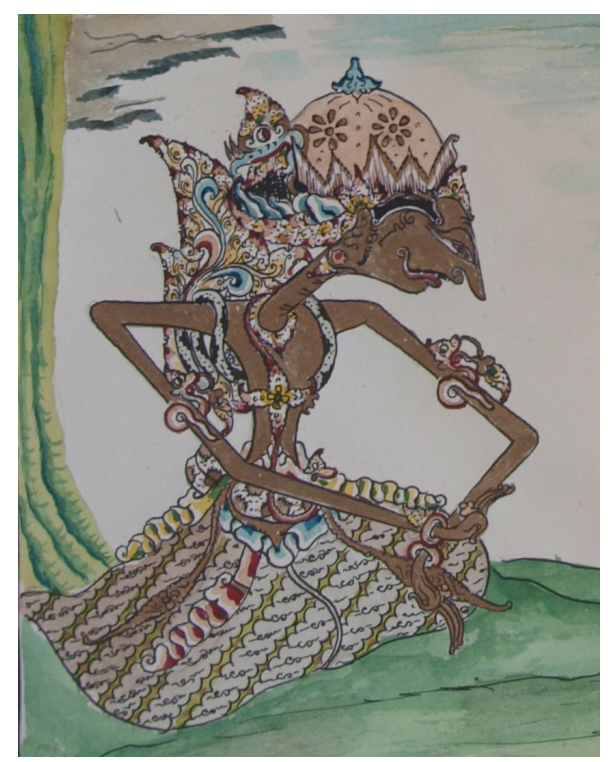

Illustration 3. Prabu Watu Gunung. (D Or. 410).

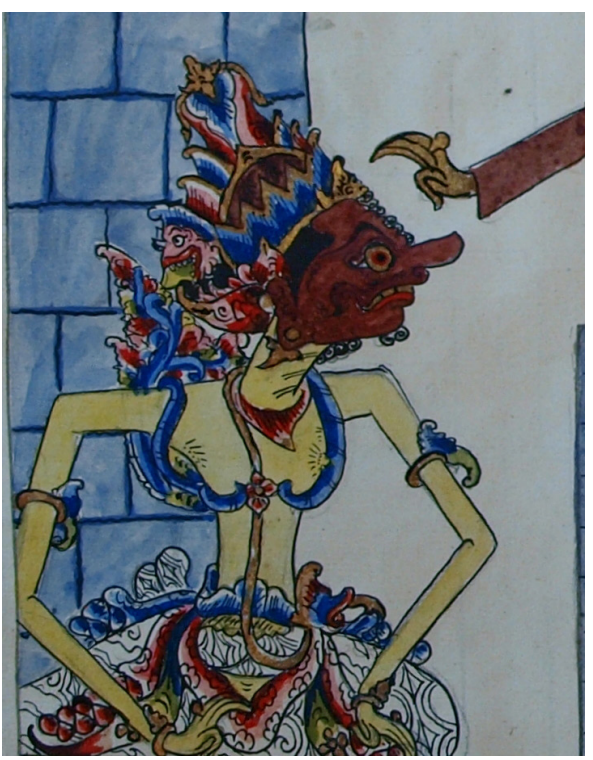

Illustration 4. Prabu Watu Gunung. (Cod.Or. 6405).

In Illustration 3 from D Or. 410, the king is depicted as a humble, refined figure with his head bowed to the ground showing his respect for the serpent god, Antaboga, and his daughter, Nagagini, who represent his wuku. Although he seems to have been portrayed in wayang style, his headdress does not resemble that of the real Watu Gunung wayang puppet, which is a crown rather than the helmet-like object he wears here which is reminiscent of the headdress of Adipadi Karna in the wayang purwa. In Illustration 4 from Cod.Or. 6405, the king does wear the expected crown but he looks up defiantly and with his red face, round eye, and big nose he is depicted as coarse and unrefined, in no way resembling the king in the first illustration or that of the real Watu Gunung wayang puppet who lowers his gaze slightly. That Illustrations 3 and 4 depict the same figure as having different characters is interesting because it might mean that the illustrations were not made to demonstrate the characteristics of the wukus as easy guides to understanding the characters of the persons born in particular wukus. It could perhaps be taken as an indication that the manuscripts were indeed not made for Javanese users but commissioned for or by people for whom these matters were inconsequential. 
Based on their hairstyles, the next two figures (Illustrations 5 and 6) depict Wayang and Dhukut from Cod.Or. 12.332 and have been inspired by the puppets of the wayang gedhog rather than of the wayang purwa. In this manuscript both the style of the wayang purwa and that of the wayang gedhog were used as inspiration, although the former features much more prominently than the latter.

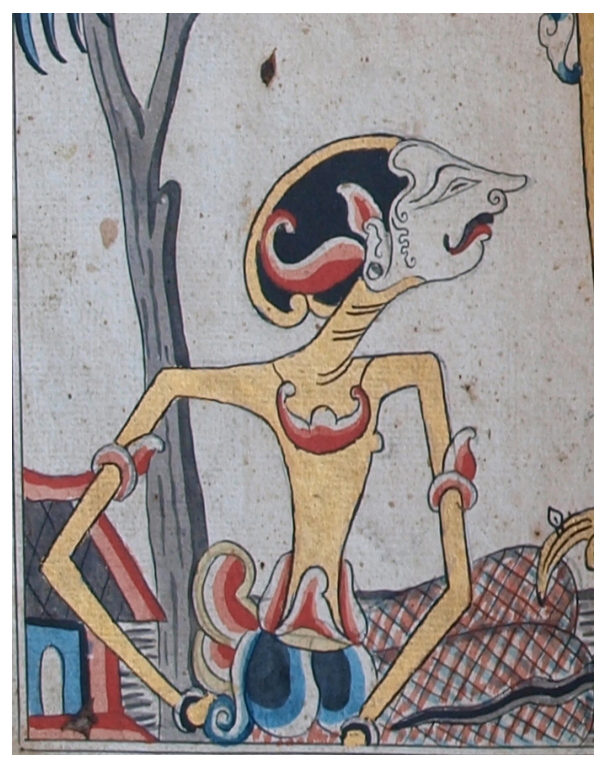

Illustration 5. Wayang. (Cod.Or. 12.332).

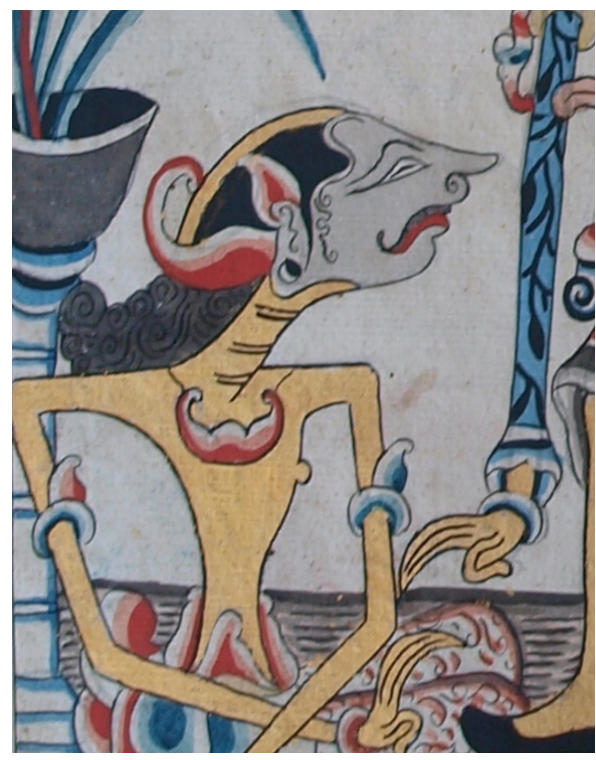

Illustration 6. Dhukut. (Cod.Or. 12.332).

Generally speaking, and if we continue to use the term "wayang iconography", Cod.Or. 2230 resembles the style of Yogyakarta, Cod.Or. 6446 is the style of Yogyakarta whereas Cod.Or. 6405, Cod.Or. 12.233, and D Or. 410 use the style of Surakarta.

\section{TEN MANUSCRIPTS COMPARED}

I compare the three Wukus Galungan, Mondhasiya, and Marakeh from ten manuscripts. ${ }^{28}$ One eye-catching difference between the manuscripts is that only Cod.Or. 6446 and Cod.Or. 12.332 portray the characters that gave their names to the wukus and, although it might be a coincidence, they also have illustrations of other divinatory elements. Because D Or. 410 is a commissioned gift, the absence of illustrations of the combinations of days can probably be explained from this fact. The same holds true of Berlin Ms. or. oct. 4036, which was also commissioned. Cod.Or. 11.650 does not include illustrations of the gods, and the trees and such or of Sinta, Landep, and Watu Gunung and their children. Hence it stands out from the rest of the manuscripts used here; it gives illustrations of the day-combinations, though. 


\section{WUKU GALUNGAN}

The main differences between the manuscripts for Wuku Galungan are that Cod.Or. 2230 has an illustration of god Wisnu and the tree Wijayakusuma rather than god Kamajaya and the tree Tangan while MSS Jav 36 (Illustration 7) has god Dhewa rather than Kamajaya. The only illustrations in which Kamajaya holds a spear are MSS Jav 36 and Add MS 12338 in which he is also not depicted as the god he is as in the other illustrations but as a younger man. In these manuscripts the trees are also curiously depicted compared to their counterparts in the other manuscripts (See pictures in Illustration 8) and in MSS Jav 36 the tree is even placed under the god. Incidentally, Cod.Or. 6446 does not contain a picture of the water vessel which the others have and also here the god is depicted as a younger man but wearing a turban rather than the curly hairstyle in the form of a shrimp claw (supit urang) he wears in the other illustrations. Kamajaya carries a Javanese dagger (keris) only in Cod. Or. 12.332 and D Or. 410.

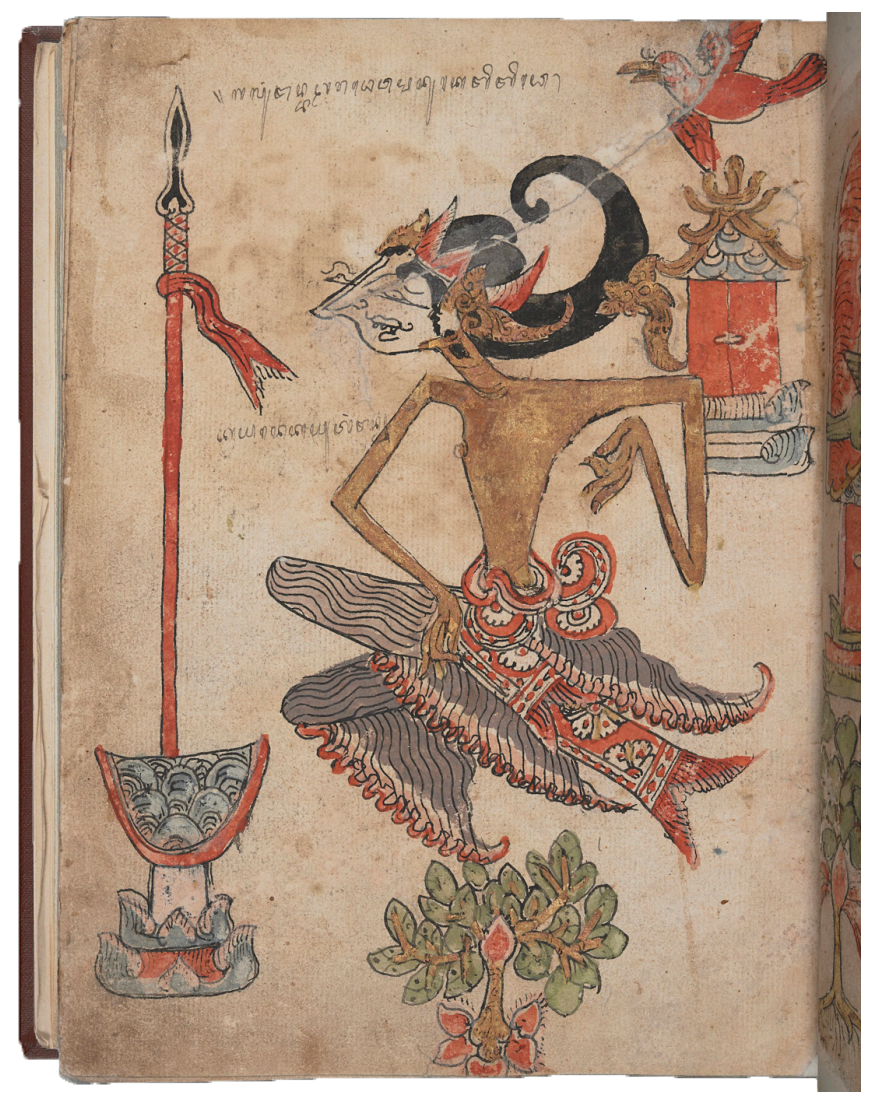

Illustration 7. Galungan with god Dhewa, bird Bibidho, and tree Tangan (detail). (British Library, MSS Jav 36). 


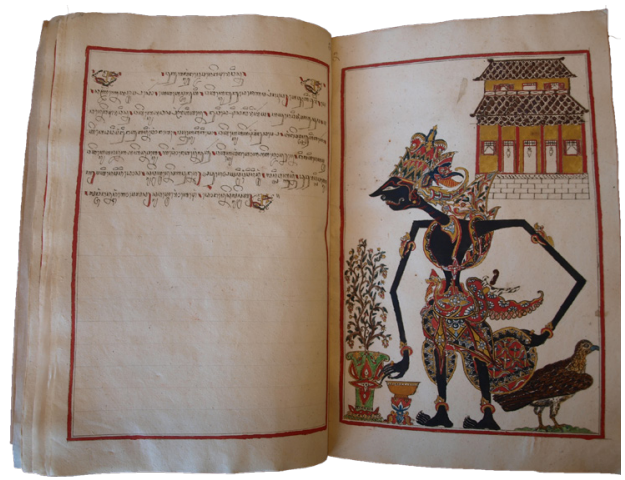

God Bathara Wisnu, bird Bebidho, and tree Wijayakusuma. (Cod.Or. 2230).

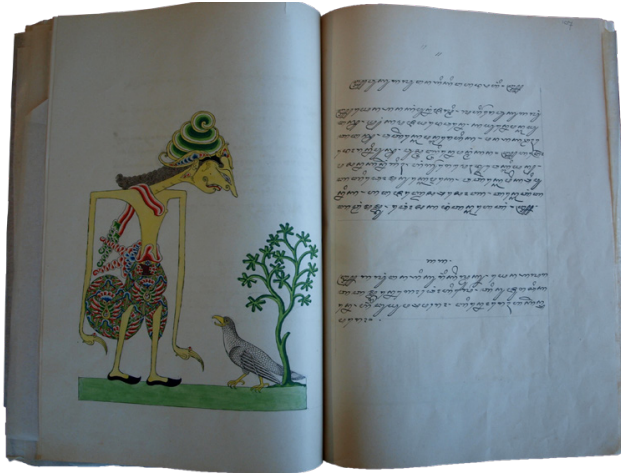

God Bathara Wisnu, bird Bebidho, and tree Wijayakusuma. (Cod.Or. 2230).

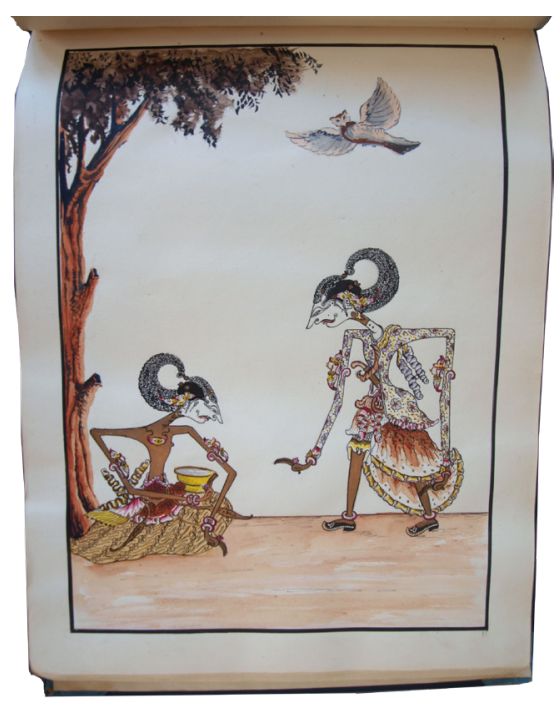

God Kamajaya. (D Or. 410).

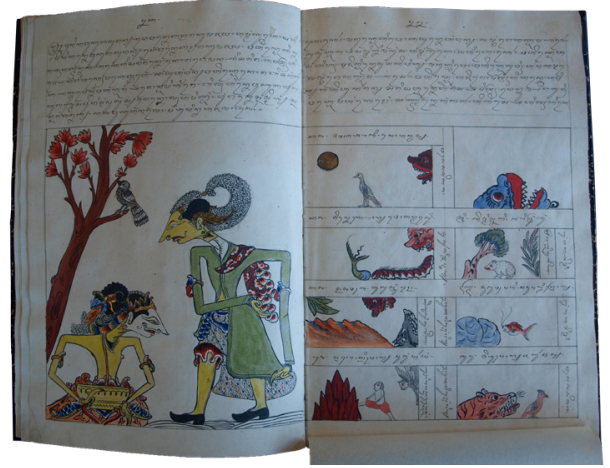

God Bathara Kumajaya, bird Bidho, and tree Tangan. (Cod.Or. 6405).

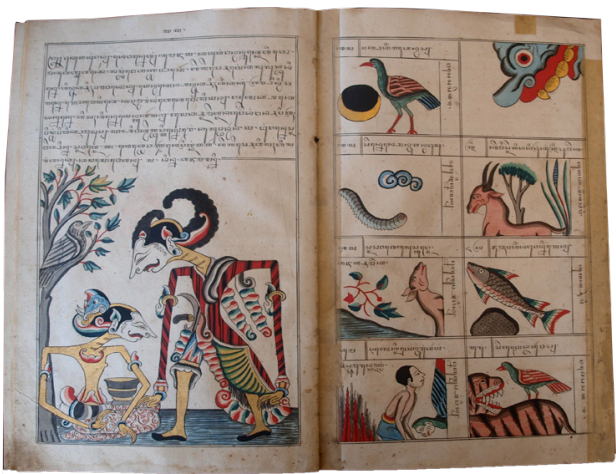

God Bathara Kumajaya, bird Bidho, and tree Tangan. (Cod.Or. 6405).

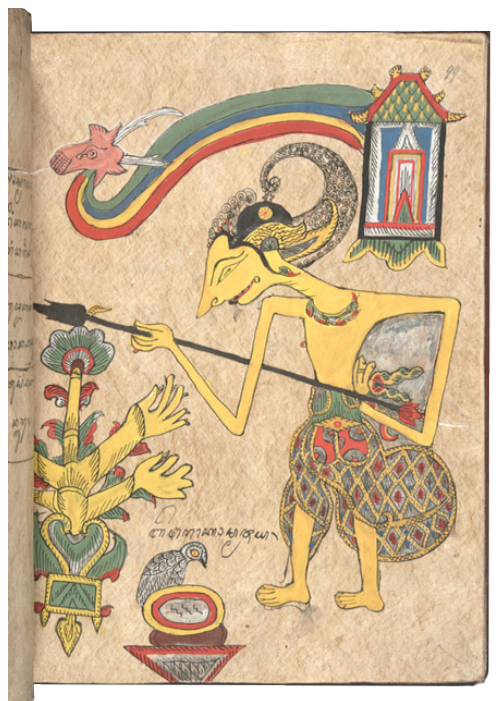

God Kamajaya, bird Bibidho, and tree Tangan. (Add MS 12338).

Illustration 8. Wuku Galungan as illustrated in six manuscripts. 


\section{WuKu MONDHASIYA}

Illustration 9 shows how Wuku Mondhasiya is shown in MSS Jav 36. In the following depictions in Illustration 10 we see the following. In Cod.Or. 2230, Wuku Mondhasiya is represented by the goddess Durga while in all the others the deity is god Brahma (spelled variously). In all cases the bird is Plutuk Bawang (spelled variously). In three cases the tree is Asem, in two Kamal and in one Sinom. Brahma carries an umbul-umbul flag only in Cod.Or. 6405, MSS Jav 36, and Add MS 12338. Brahma carries a keris in Cod.Or. 6405, Cod.Or. 12.332, and D Or. 410. He is barefoot in MSS Jav 36 and Add MS 12338 while in the others he wears the shoes only gods may wear in wayang puppets, whereas in the former he looks up, in the latter he faces down.

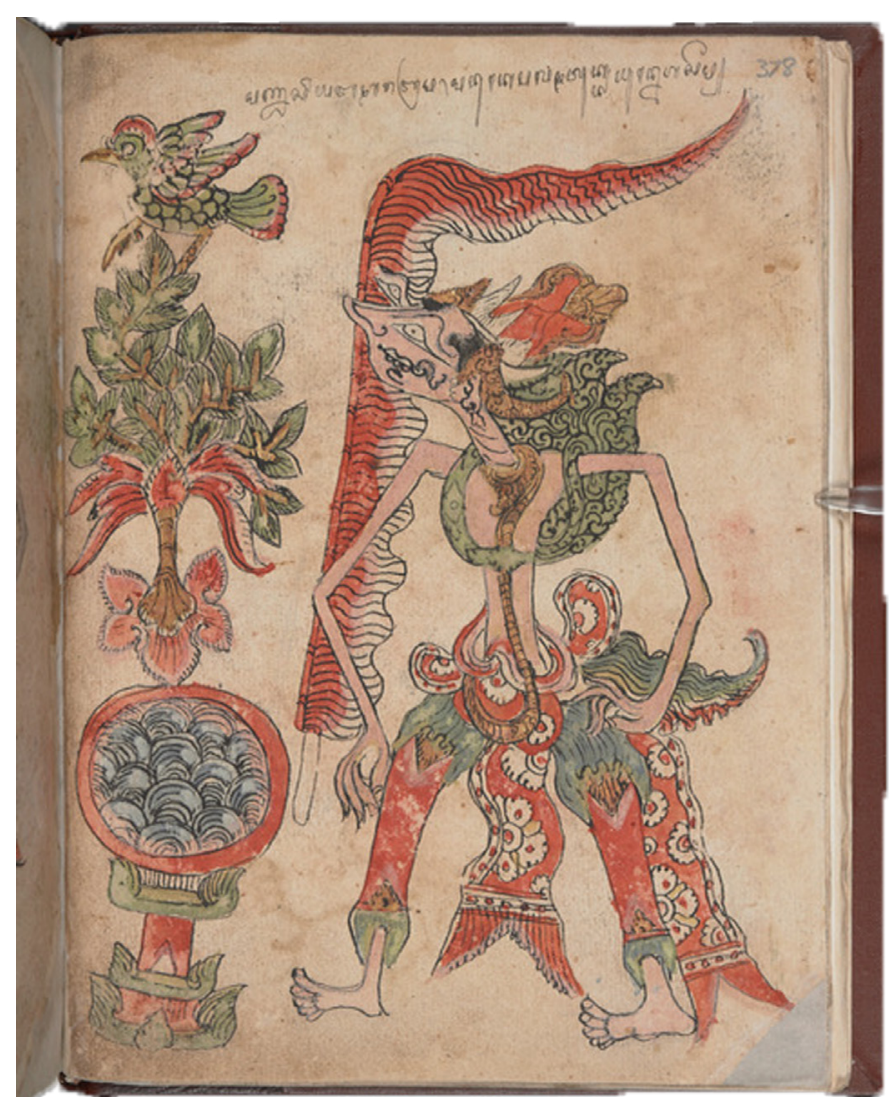

Illustration 9. Wuku Mondhasiya with god Brama, bird Palatuk, and tree Asem (detail). (British Library, MSS Jav 36). 


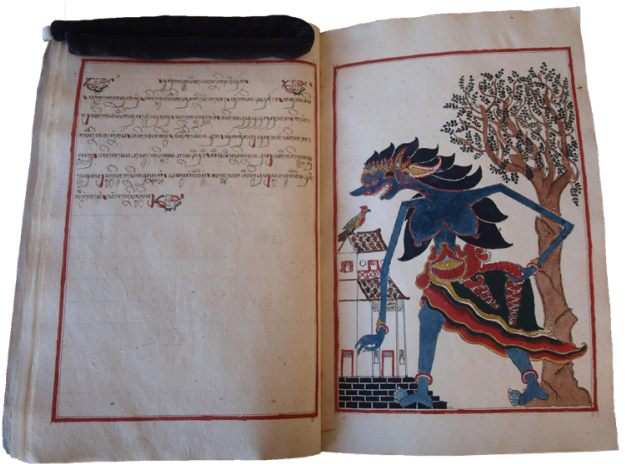

Wuku Mondhasiya with the goddess Bathari Durga, bird Plutuk Bawang, and tree Asem. (Cod.Or. 2230).

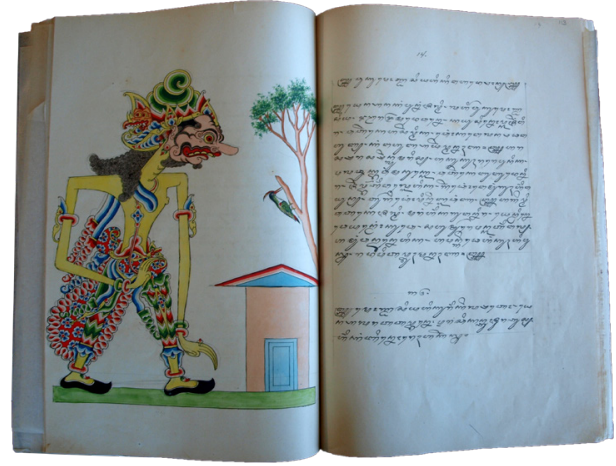

Wuku Mondhasiya with god Brama, bird Palathuk Bawang, and tree Sinom. (Cod.Or. 6446).

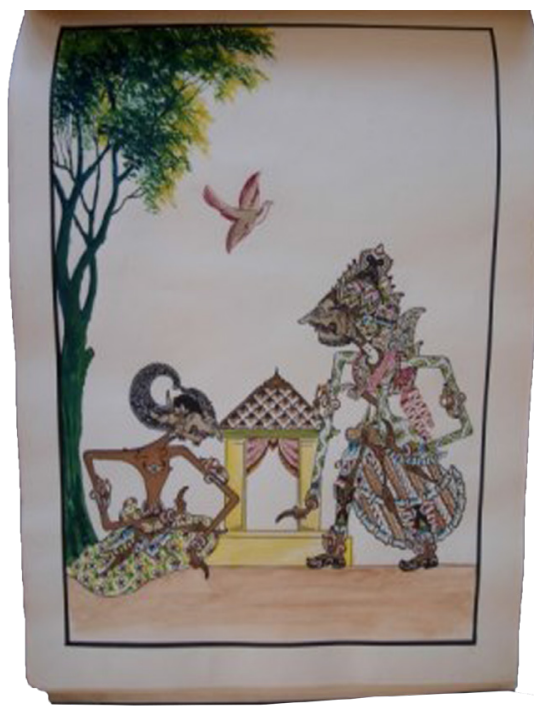

God Brahma. (D Or. 410).

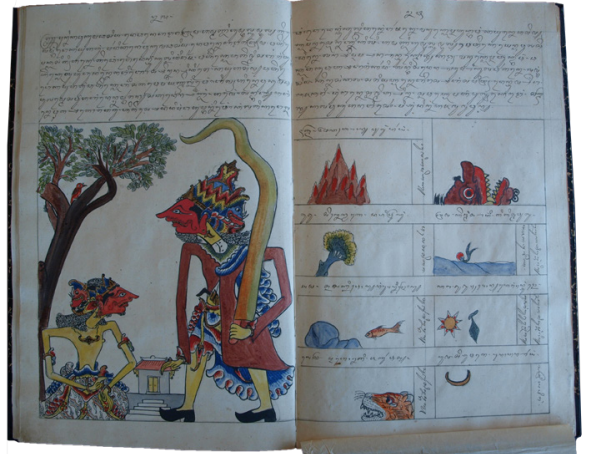

Wuku Mondhasiya with god Bathara Brahma, bird Pletuk Bawang, and tree Asem. (Cod.Or. 6405).

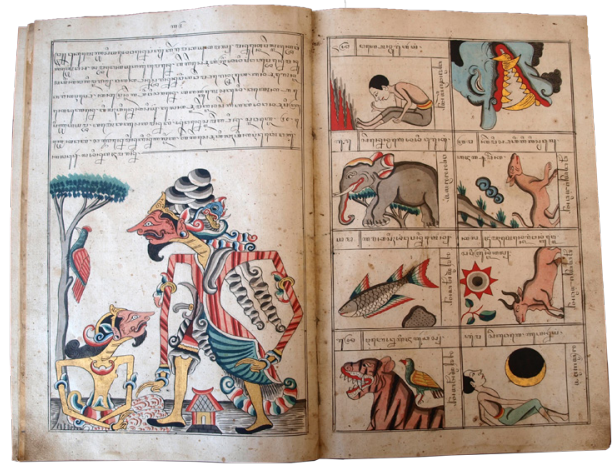

Wuku Mondhasiya with god Berama, bird Pelatuk Bawang, and tree Kamal. (Cod.Or. 12.332).

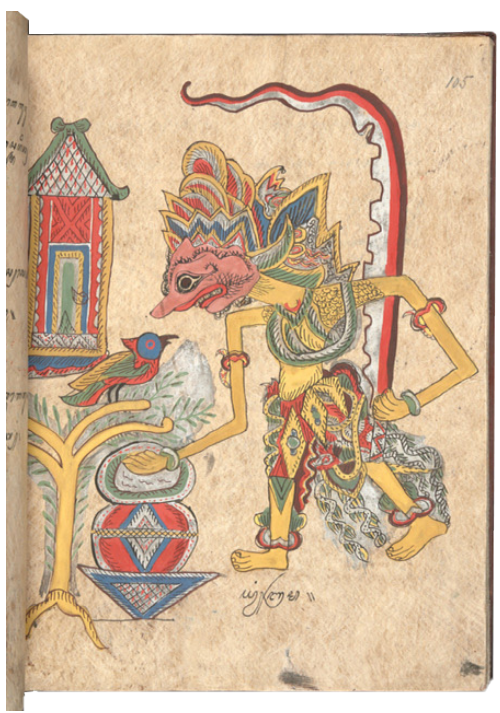

God Brama, bird Pelatuk, and tree Asem. (Add MS 12338).

Illustration 10. Wuku Mondhasiya as illustrated in six manuscripts. 


\section{WUKU MARAKEH}

Illustration 11 shows how Wuku Mondhasiya is shown in MSS Jav 36. In the following depictions in Illustration 12 we see that for Wuku Marakeh, Cod.Or. 2230 is again an exception as it portrays god Panyarikan rather than Surenggana (spelled variously). The texts of all manuscripts agree that there is no bird, including MSS Jav 36 in which a bird has been depicted in the illustration nonetheless (see Illustration 11). In all manuscripts, the tree is Trengguli (spelled variously). Note that Cod.Or. 2230 is the only one to omit the building which is represented in all the other manuscripts. Only in Cod.Or. 6446 does Surenggana not carry a keris. The depiction of Surenggana differs enormously in the manuscripts, from a long-haired youth in MSS Jav 36, an enormous blue demon-like creature in Cod.Or. 6446 to a refined god in Cod. Or. 12.233 and D Or. 410.

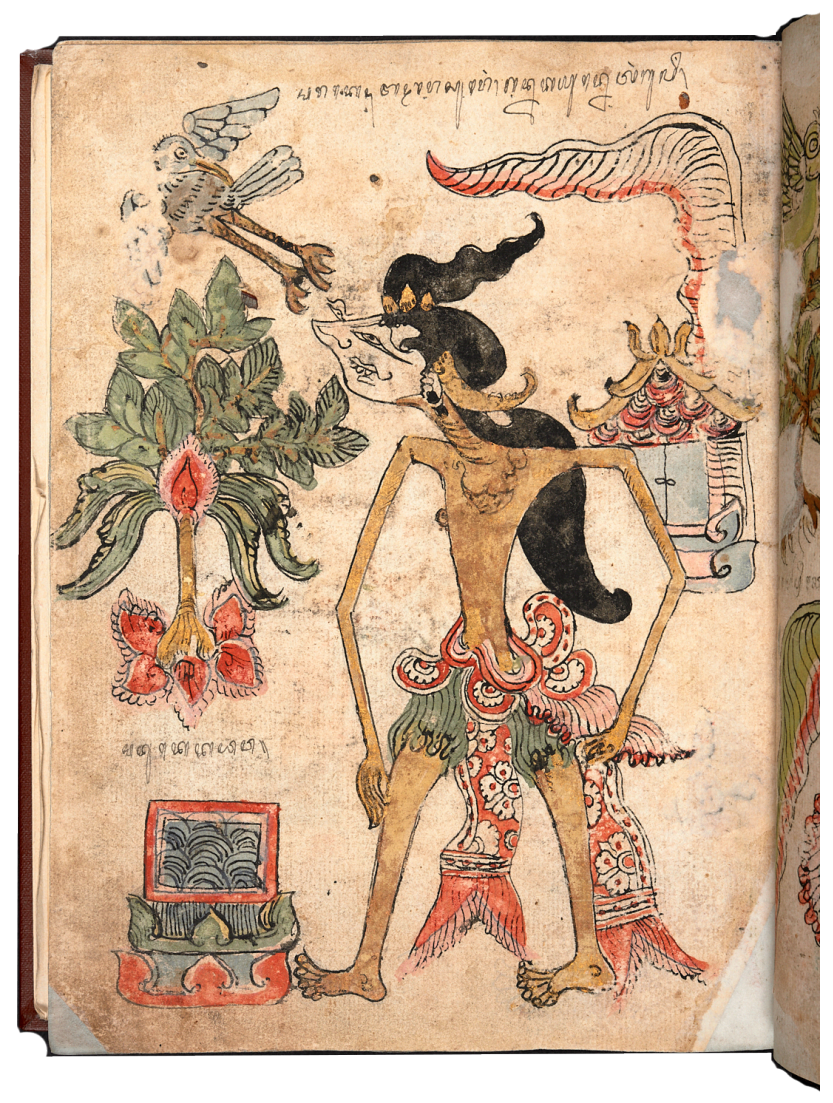

Illustration 11. Wuku Marakeh with god Surenggana, no bird mentioned but depicted, and tree Tangguli (detail). (British Library, MSS Jav 36). 


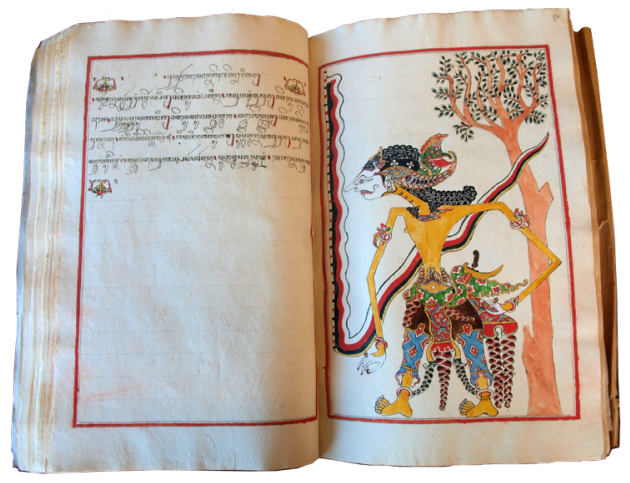

Wuku Marakeh with god Penyarikan, no bird, and tree Trenggulu. (Cod.Or. 2230).

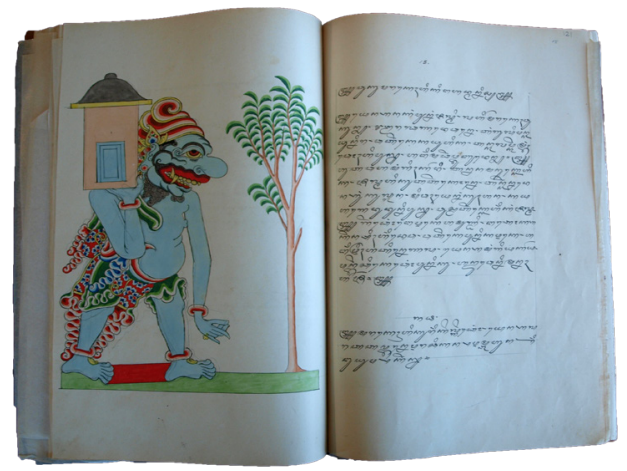

Wuku Marakeh with god Gana, ${ }^{29}$ no bird, and tree Tangguli. (Cod.Or. 6446).

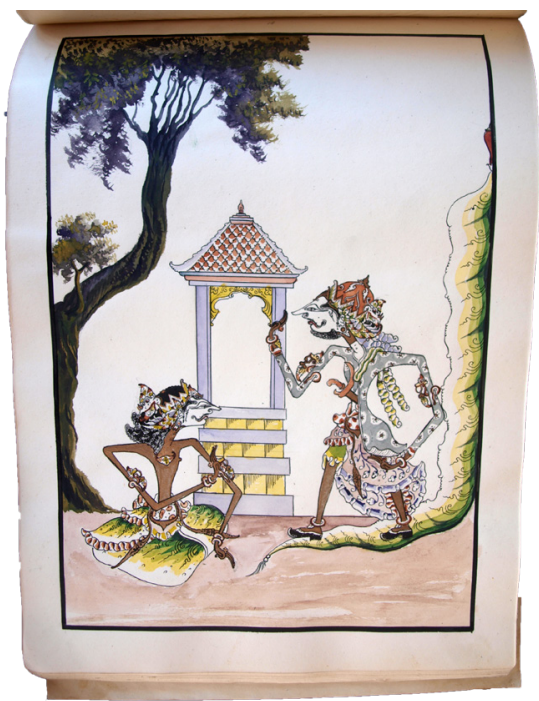

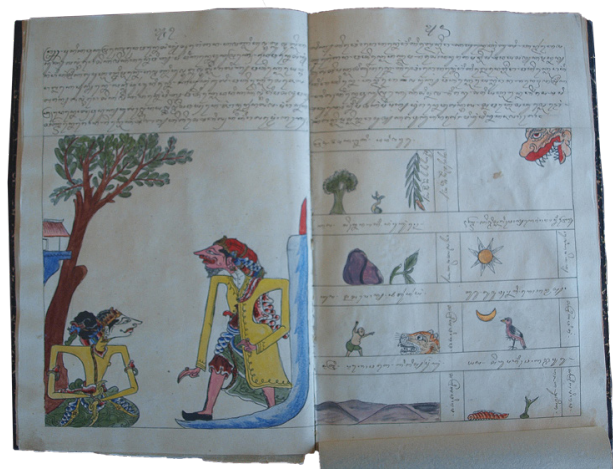

Wuku Marakeh with god Srenggana, no bird, and tree Trengguli. (Cod.Or. 6405).

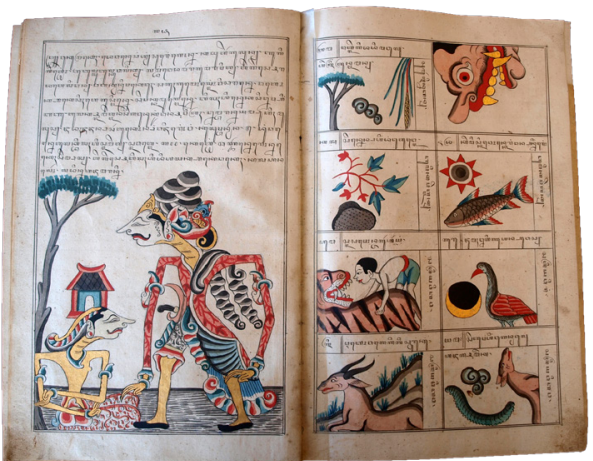

Wuku Marakeh with god Surenggana, no bird, and tree Tergulun. (Cod.Or. 12.332).

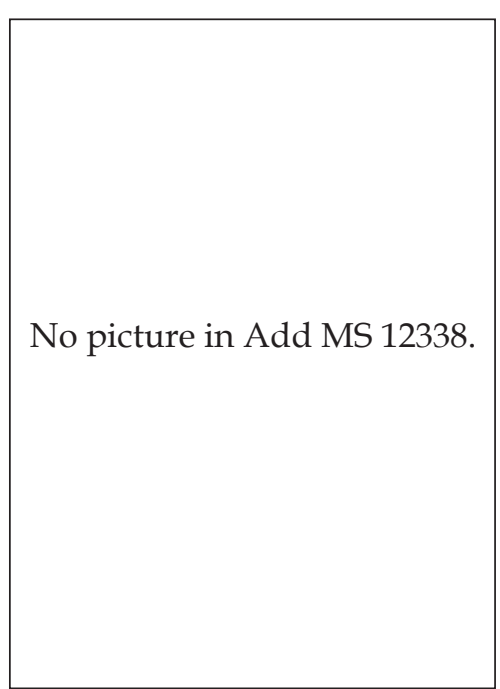

God Surenggana. (D Or. 410).

Illustration 12. Wuku Mondhasiya as illustrated in five manuscripts.

29 Gana as an abbreviation of Trenggana and not to be confused with the god of Wuku Sungsang, Gana. 
COD.Or. 11.650

In the manuscript of Leiden University Libraries Cod.Or. 11.650 (Illustrations 13-15) the pages look completely different from the others as shown below.
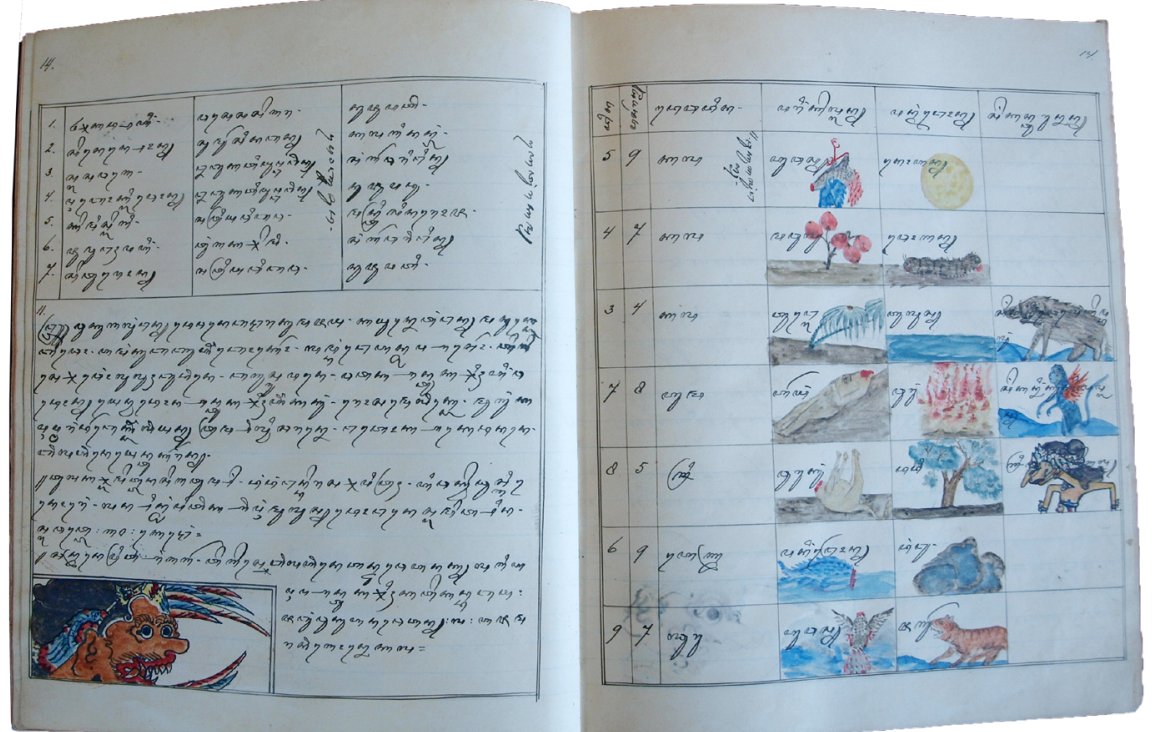

Illustration 13. Wuku Galungan (with god Kumajaya, bird Bidho, and tree Tangan in the text). (Cod.Or. 11.650).
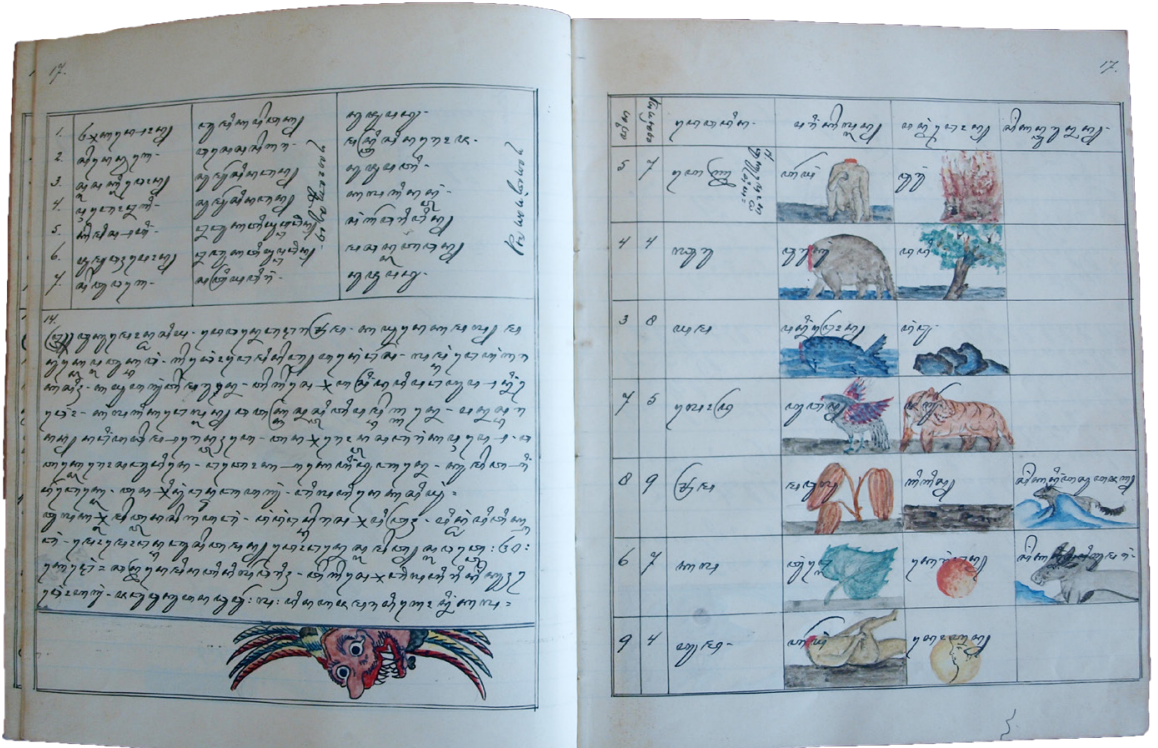

Illustration 14. Wuku Mondhasiya (with god Brama, bird Platuk Bawang, and tree Kamal in the text). (Cod.Or. 11.650). 
None of the essential wuku elements - god, bird, tree, building, water vessel, and umbul-umbul flag - was illustrated but other divinatory elements were depicted. Here we find only a winged head looking to its right, left or to the ground (which probably represents god Kala, the God of Time, and the places where he lurks to engage in his destructive activities). The entire manuscript merits careful study as most of the creatures which offer the divinations for day combinations either have decapitated bodies as in Illustrations 13 and 14 or severed heads as in Illustration 15.
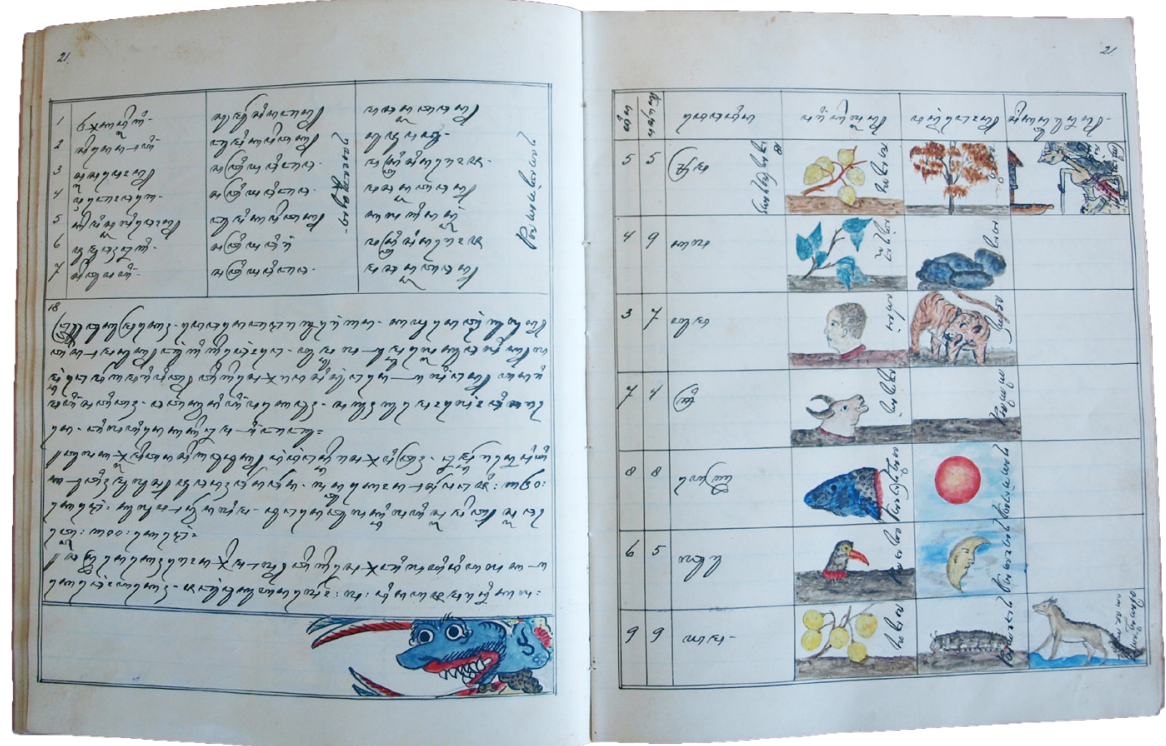

Illustration 15. Wuku Marakeh (with Surenggana, bird, and tree Trenggulun, and no bird in the text). (Cod.Or. 11.650).

\section{BERLIN Ms. OR. OCT. 4036 AND BL OR 15922}

Two other manuscripts which stand out are the commissioned manuscript Berlin Ms. or. oct. 4036 which is in black and white and BL Or 15922 which has a entirely different make-up than any of the other manuscripts. In Berlin Ms. or. oct. 4036, each depiction of the wukus has also been given the head of a figure either on the left, right or top of the picture (probably god Kala as in Cod.Or. 11.650). In Illustration 16 follow the pictures of the three Wukus Galungan, Mondhasiya, and Marakeh in Berlin Ms or oct 4036.

Illustrations 17-19 from British Library BL Or 15932 show the illustrated parts of the pages of the same three wukus I showed for the other manuscripts. ${ }^{30}$ The depictions of the gods in from the Collin Mackenzie Collection bear no relation whatsoever to the wayang style. The depictions are much more human and the birds and the trees have been depicted in a more naturalistic style. Because of the way they have been placed in relation to each other, there is no

30 The accompanying text is on the same pages below the illustrations. 
interaction between the different elements in the illustrations as is suggested in other manuscripts.

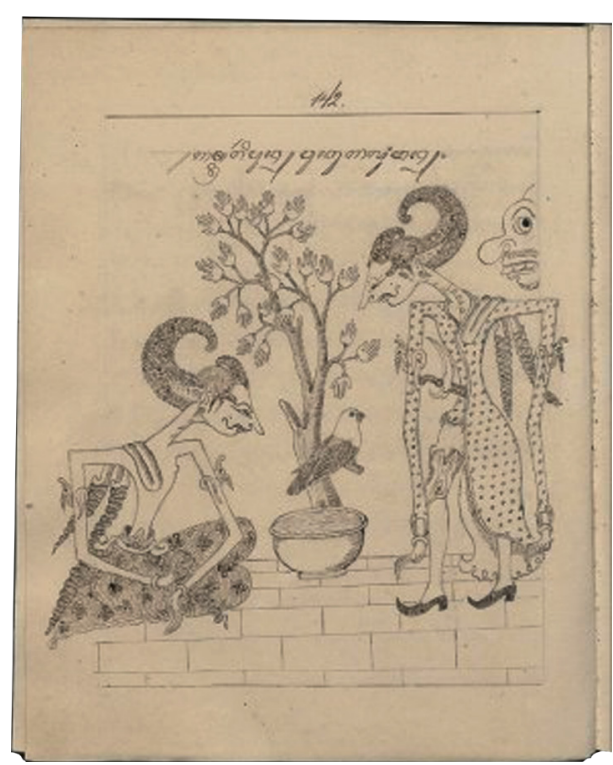

Wuku Galungan with god Kamajaya, bird Bidho, and tree Tangan.

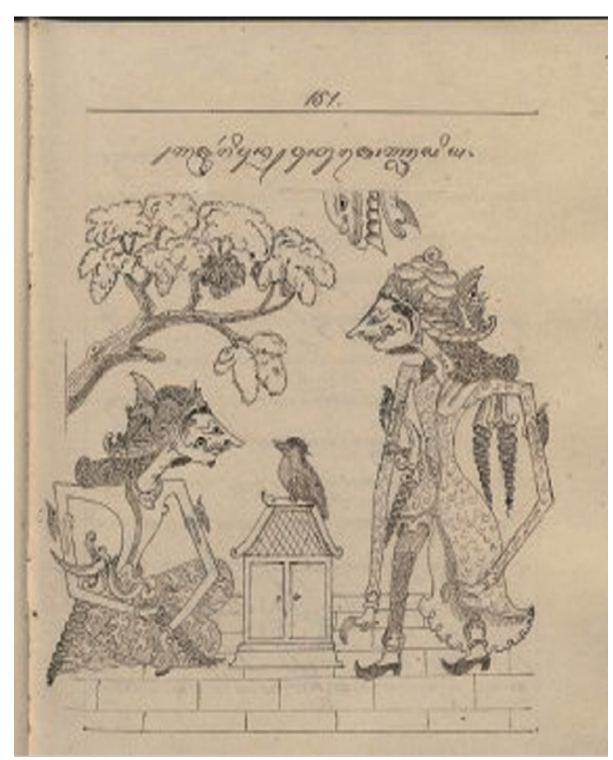

Wuku Mondhasiya with god Brama, bird Platuk, and tree Asem.

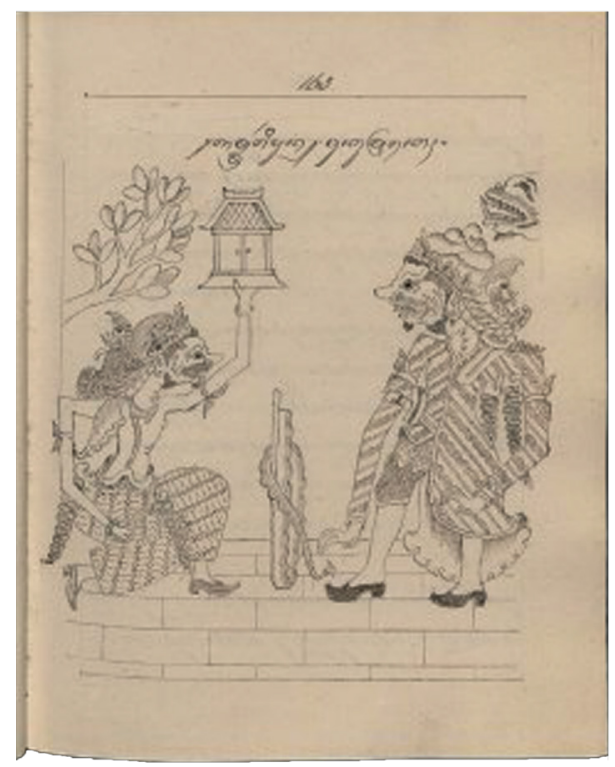

Wuku Marakeh with god Surenggana, and tree Trengguli.

Illustration 16. Wukus Galungan, Mondhasiya, and Marakeh. (Berlin Ms. or. oct. 4036). 


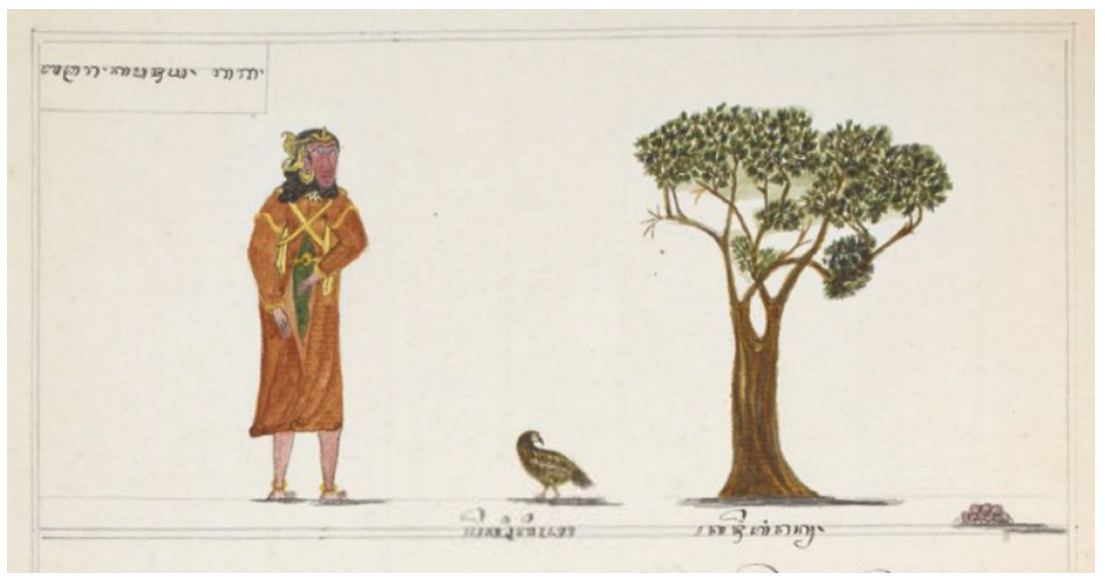

Illustration 17. Wuku Galungan with god Kamajaya, bird Bidho, and tree Tangan (detail). (BL Or 15932).

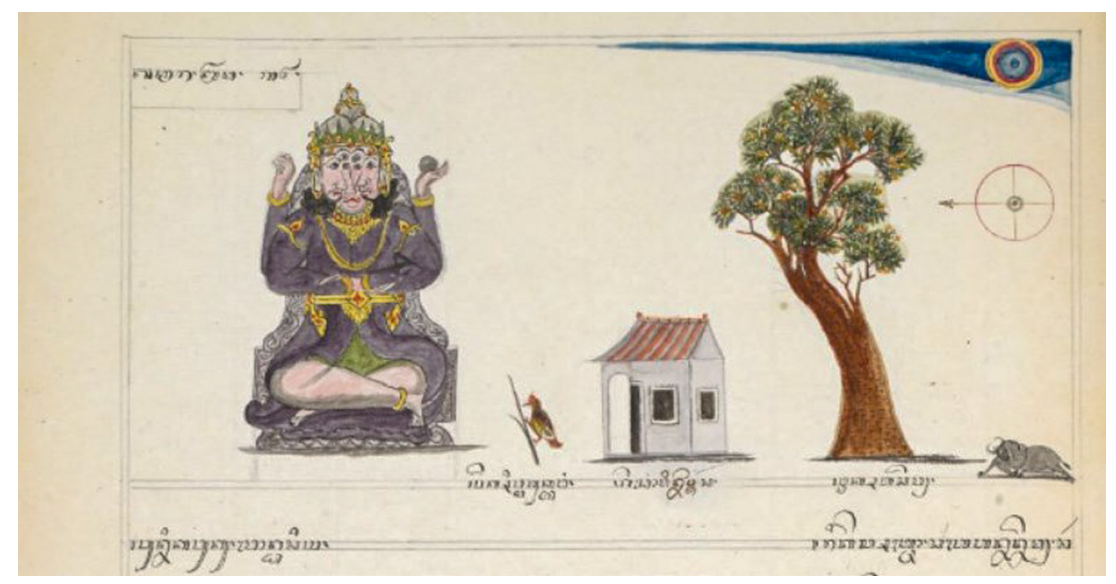

Illustration 18. Wuku Mondhasiya with god Brahma, bird Plathuk Bawang, and tree Asem (detail). (BL Or 15932).

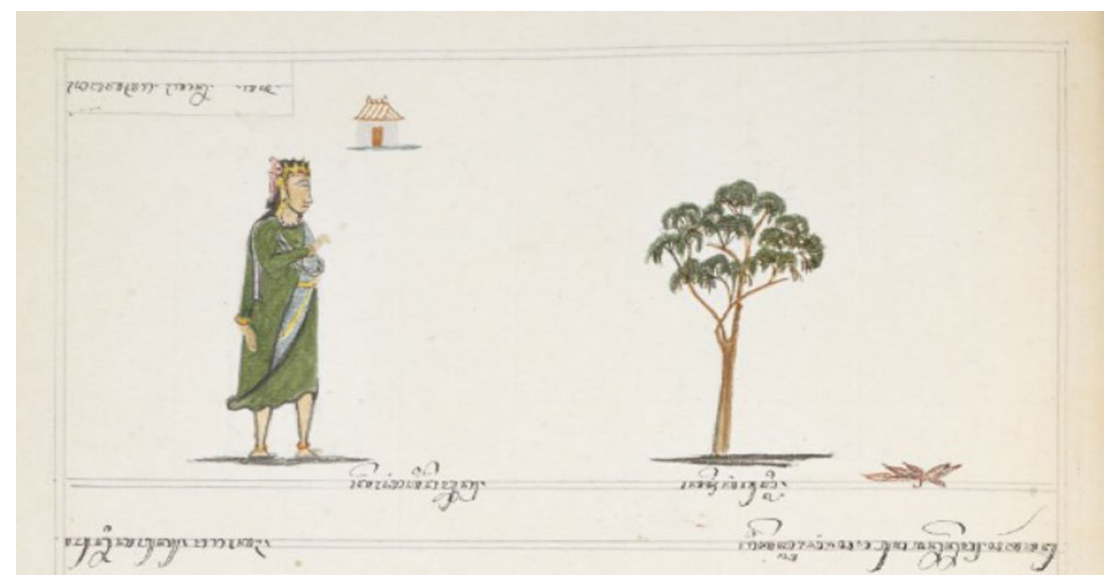

Illustration 19. Wuku Marakeh with god Gana, no bird, and tree Tangguli (detail). (BL Or 15932). 


\section{TEXT AND ILLUSTRATIONS}

In MSS Jav 36, the illustrations of the wukus continue from one page to the next without interruption of text and they only mention the names of the wukus, the birds, and trees (with exceptions, for example, Wukus Sinta, Kurantil, and Langkir for which the names of the trees are not stated). Two of the manuscripts present the pawukon text and the illustrations separately on opposite pages. Cod.Or. 2230 and D Or. 410 have the text on the left and illustrations on the right pages while Cod.Or. 6446 has the illustrations on the left and the text on the right pages. Cod.Or. 6405 and Cod.Or. 12.332 have the illustrations with the gods and other elements on the left and the illustrations of the other divination elements on the right. This is also the case with a manuscript in Museum Sonobudoyo (PR 23), which is illustrated in Kumar and McGlynn 1996. ${ }^{31}$ Even here differences occur. Cod.Or. 6405 has the text running over both pages, while Cod.Or. 12.332 has the text on the left page only. All this indicates the degree of freedom about the mise en page of the illustrations and the accompanying texts in the manuscripts. Illustrations might be consistent in one manuscript so that all depict the gods, buildings, birds, trees, and so on, while others are not so consistent and the illustration of one wuku contains more elements than that of another, even though these elements are stated in the accompanying texts. This is important as it is an indication that specific combinations of textual information and illustrations might possibly not be used to point to a specific place and time of production or of the social background of the makers/ owners and probably the commissioners of these manuscripts, because the texts seem to be quite consistently complete in all manuscripts (with minor exceptions, of course).

\section{BIRDS AND TREES}

There seems to be little consensus about how the birds and trees should be depicted and much variation is found in the way they are illustrated. Some birds, like the ayam alas (forest rooster), are easily recognizable, while others are much more difficult to identify (at least for me). Some illustrators depict the trees in a free style with lush foliage, while others opt for a simpler depiction. The trees and birds are not always put in the same position in the illustrations; some can be small and others large, as be seen in the illustrations below and in the other illustrations in this article. Note that more animals are depicted in the parts of the combinations of days and weeks in Cod.Or. 6405 and Cod.Or. 12.332 including tigers, herons, deer, boar, and fish as in the picture of Cod.Or 12.332 in Illustration 20. 


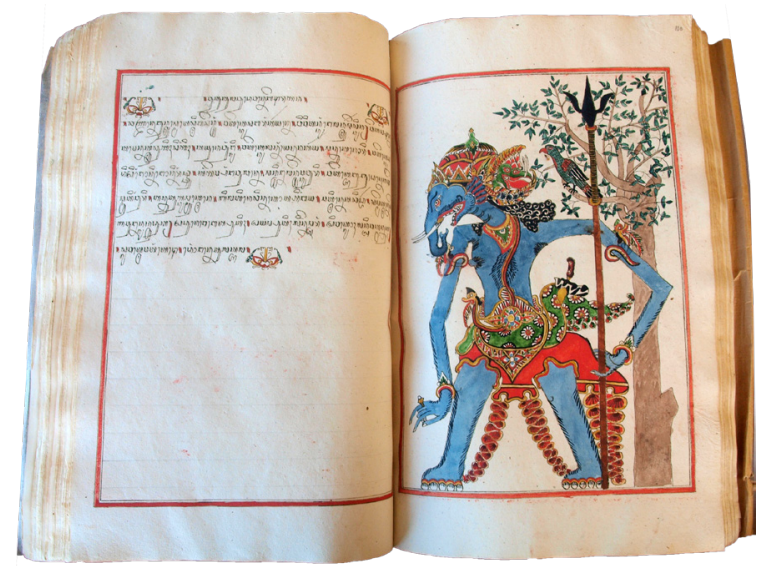

Wuku Kulawu with god Gana with tree Wungli and bird Nori. (Cod.Or. 2230).

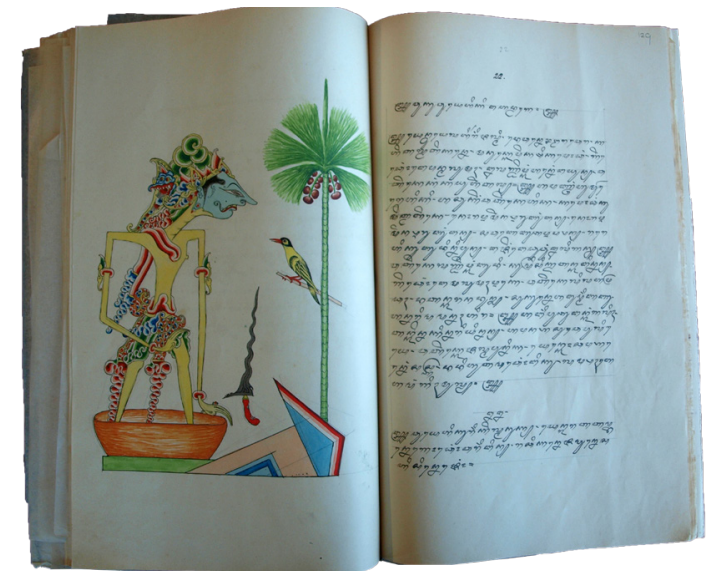

Wuku Wuye with god Wera, tree Siwalan, and bird Kapodhang. (Cod.Or. 6446).

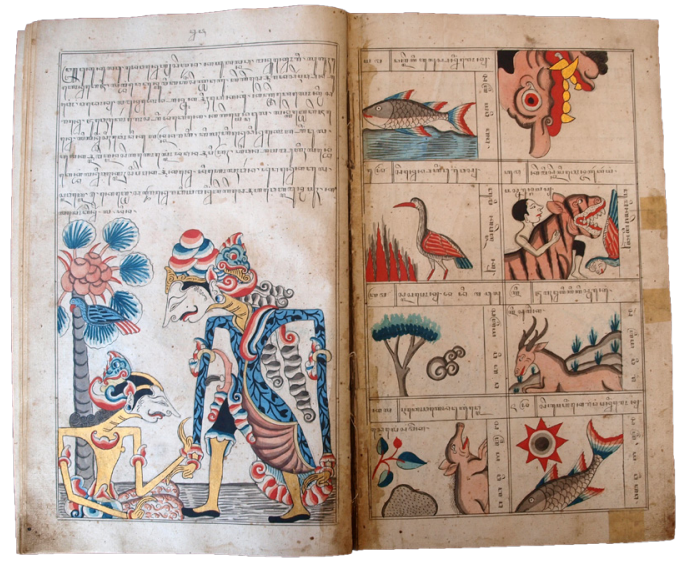

Wuku Kulawu with god Sedana, tree Talkawa, and bird Nori. (Cod.Or. 12.332).

Illustration 20. Wuku Kulawu with Bathara Gana, Wuku Wuye with Dewa Wera, and Wuku Kulawu with Hyang Sedana. 
PiCTORIAL VARIATION IN THE DEPICTION OF THE GODS

To illustrate the iconographic variation found in the manuscripts in greater detail, we shall have a look at some of the gods as presented in the manuscripts under discussion.

\section{Antaboga $a^{32}$ and Nagagini}

Illustration 21 (see sixs pictures below) shows the way the serpent god Antaboga and his daughter Nagagini are depicted in dramatically different ways in six manuscripts. The first difference is that in Cod.Or. 2230, Antaboga is the only god mentioned in the text and hence only he has been portrayed. In Cod.Or. 6446 both Antaboga and Nagagini are portrayed as serpents but only Antaboga's divine status is indicated by having himself as divine god standing on top of a serpent. In Add MS 12338 both Ontaboga and Nagagini are mentioned, but only Ontaboga is portrayed in his divine form standing on a serpent. In Berlin Ms. or. oct. 4036 both gods stand on only one serpent. These pictures contrast with Cod.Or. 6405 and Cod.Or. 12.233 in which they are portrayed as gods without any indication that they are serpents.

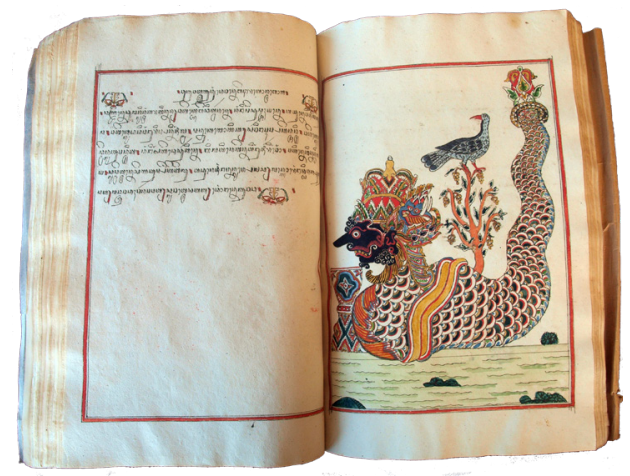

Cod.Or. 2230.

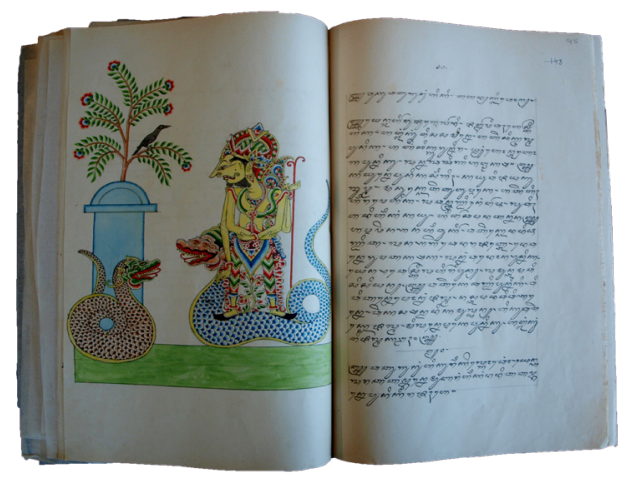

Cod.Or. 6446.

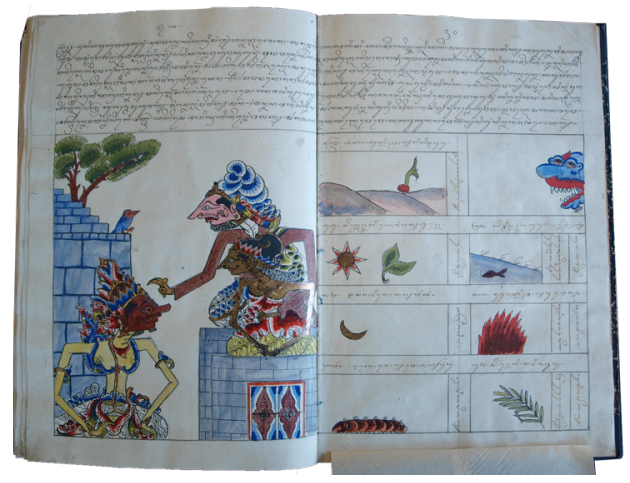

Cod.Or. 6405.

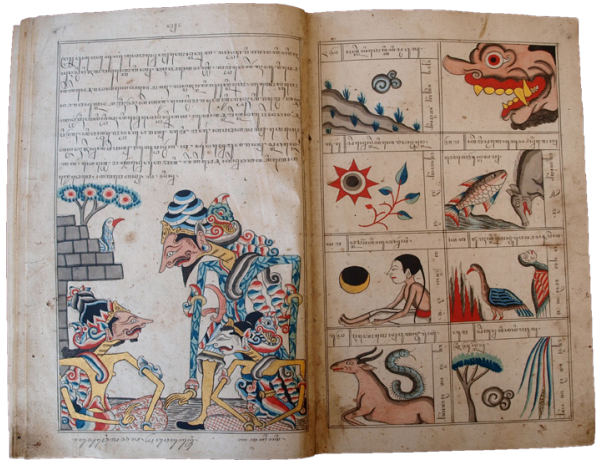

Cod.Or. 6446. 


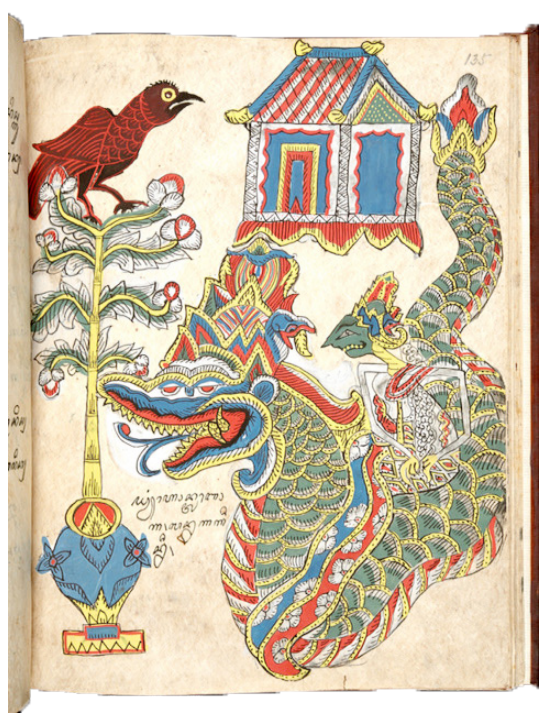

Add MS 12338.

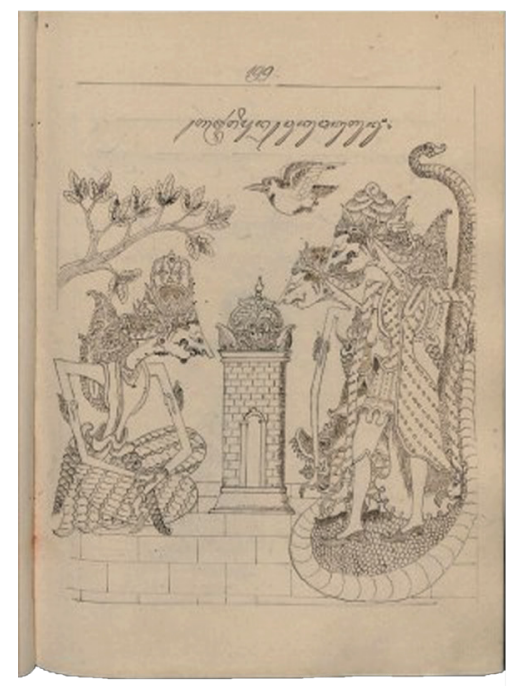

Berlin Ms. or. oct. 4036.

Illustration 21. Antaboga and Nagagini as portrayed in 6 manuscripts.

\section{Bathara Singajalma}

Another interesting difference in the iconographic depictions of a god is seen in Singajalma, the deity of wuku Wugu as can be seen in Illustrations 22 and 23. His name means Lion-man and hence he is sometimes portrayed as a humanoid god but with the head of a tiger as in Cod.Or. 6405 and D Or. 410, rather than that of a lion, but as a human-like god in Cod.Or. 2230 and in Add MS 12338. In Cod.Or. 6446 his name is reduced to Jalma (person) and he does not display any lion features. Singajalma wears divine shoes in most illustrations, but has tiger paws in Cod.Or. 6405. He is especially ferocious in the Berlin manuscript as shown in Illustration 23.

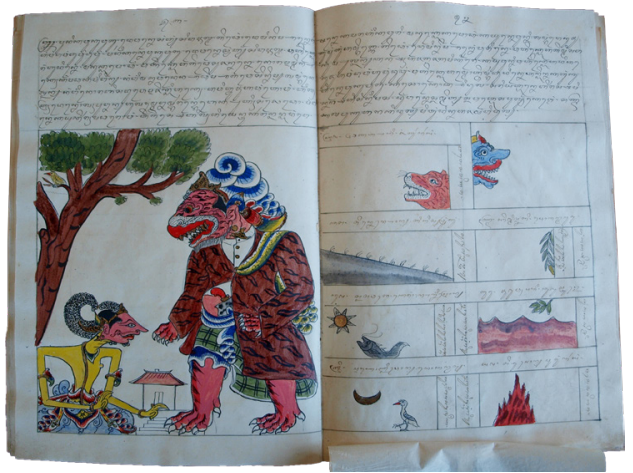

Cod.Or. 6405.

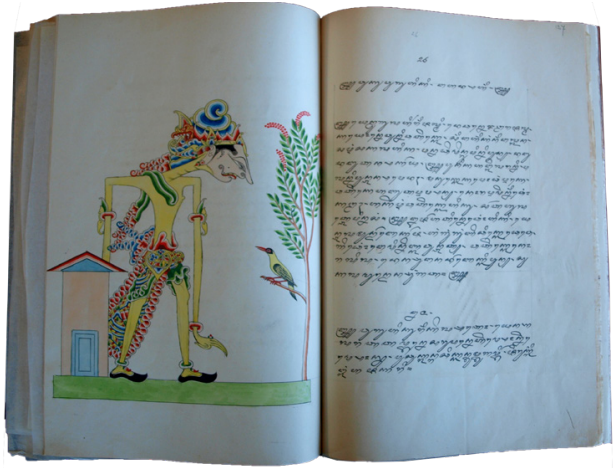

Cod.Or. 6446. 


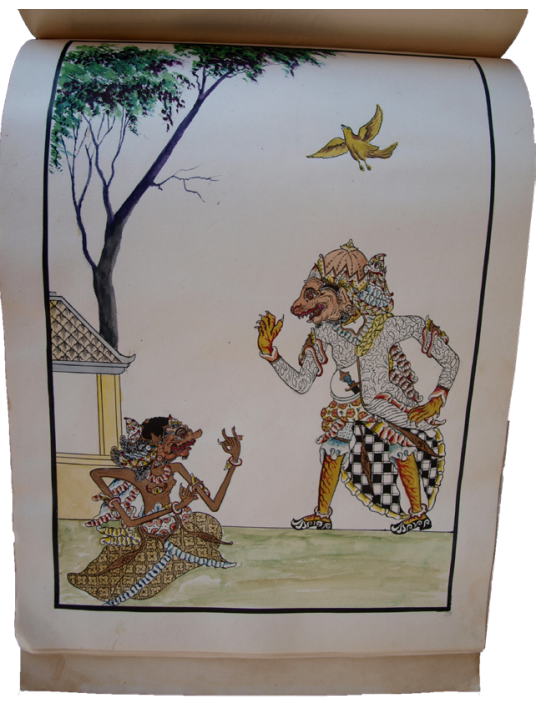

D Or. 410.

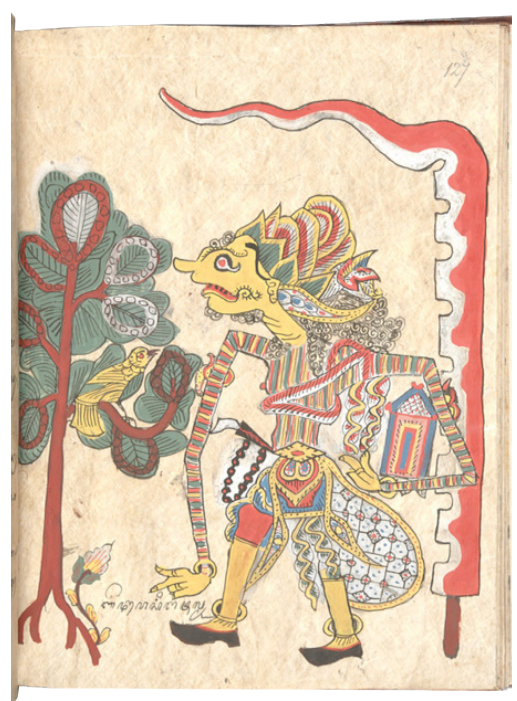

Berlin Ms. or. oct. 4036.

Illustration 22. Singajalma as portrayed in four manuscripts.

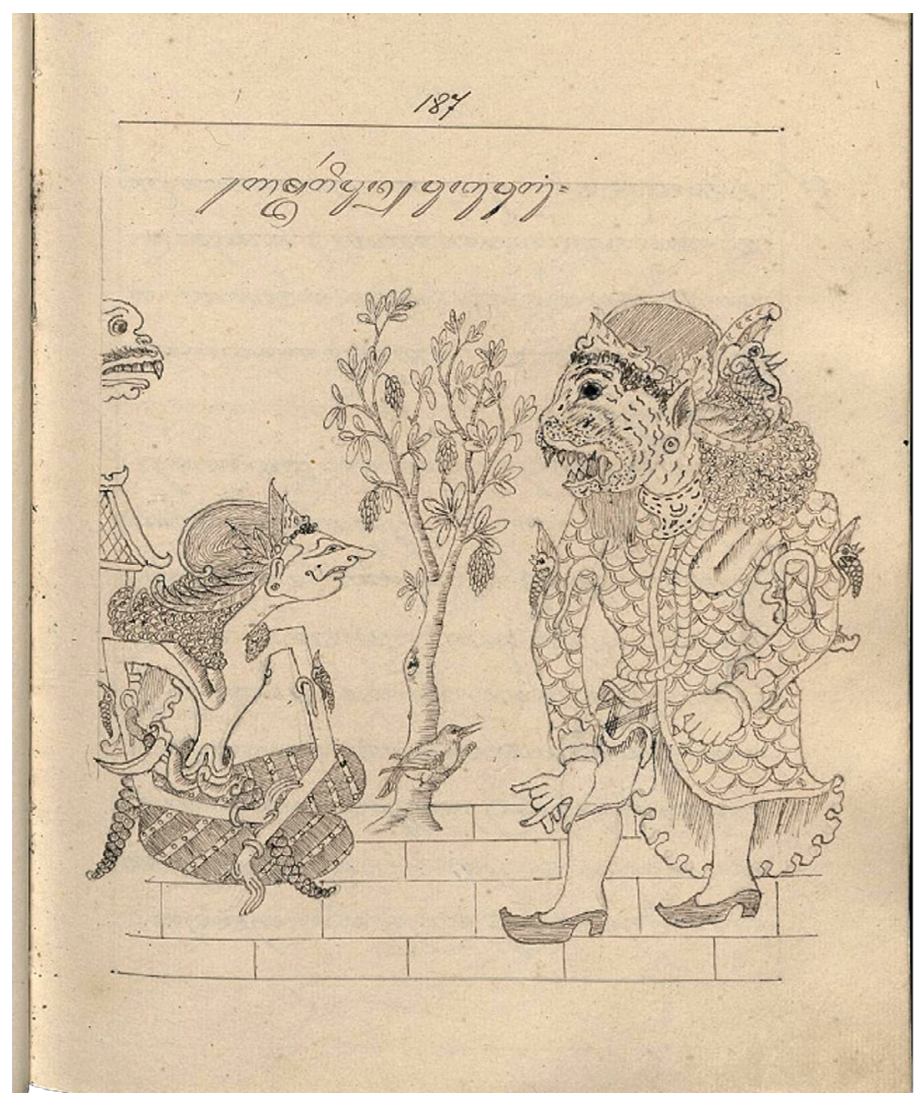

Illustration 23. Singajalma is portrayed as half-man half-tiger. The tree is Wuni and the bird is Kapodhang. (Ms. or. oct. 4036). 


\section{Bathara Gana}

Finally, we take a look at the depiction of Gana, the god of Wuku Sungsang (Illustration 24, and compare sixs pictures in Illustration 25).

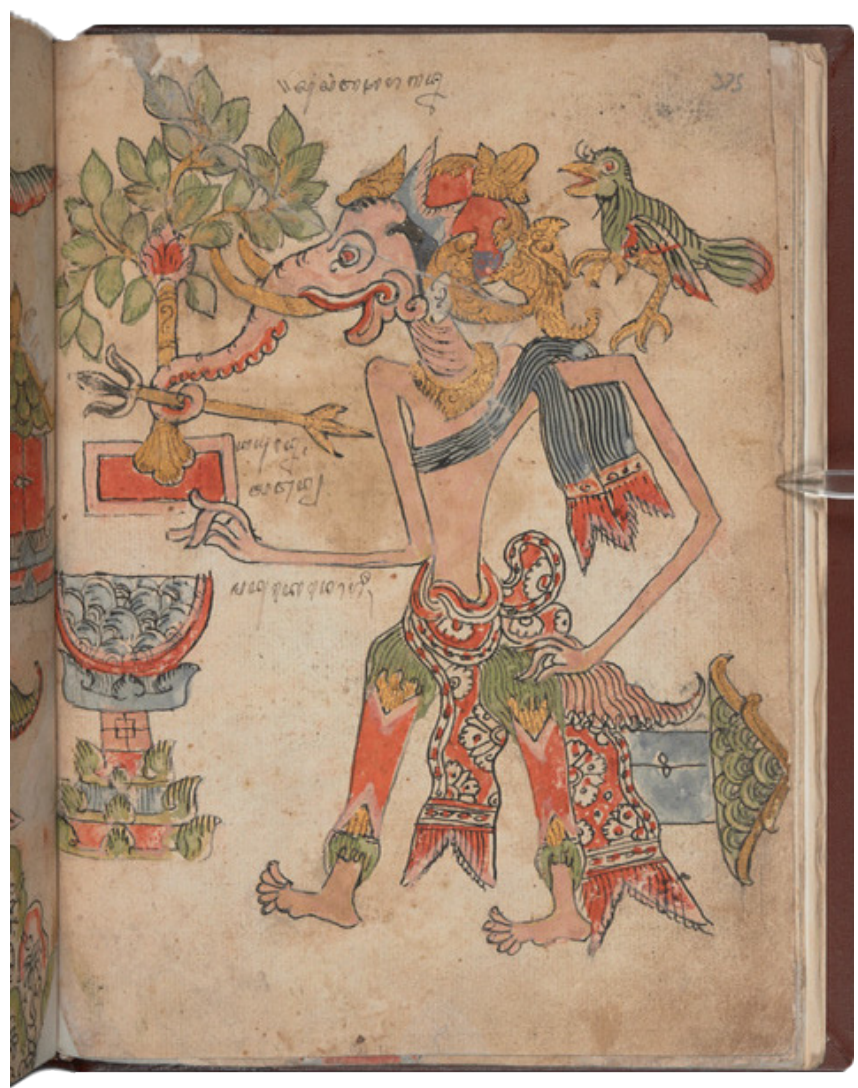

Illustration 24. Wuku Sungsang with god Gana, bird Nori, and tree Tangan. (MSS Jav. 36).

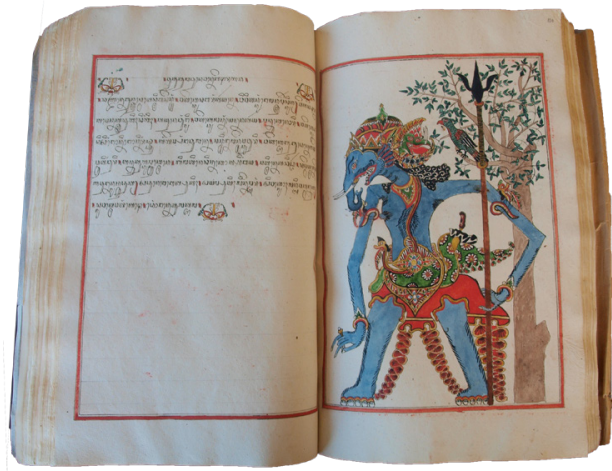

Cod.Or. $2230 .{ }^{33}$

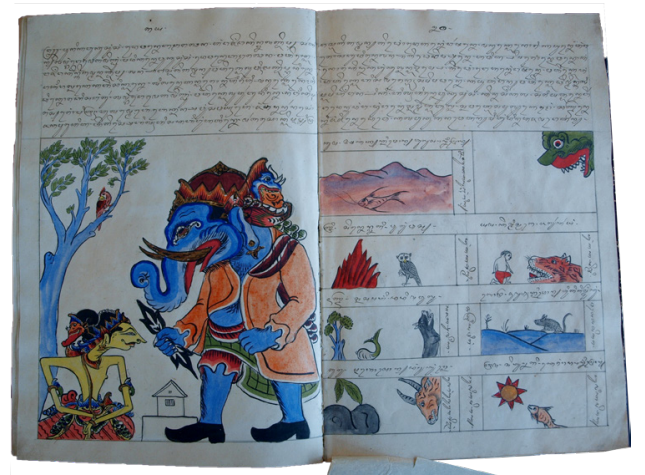

Cod.Or. 6405. 


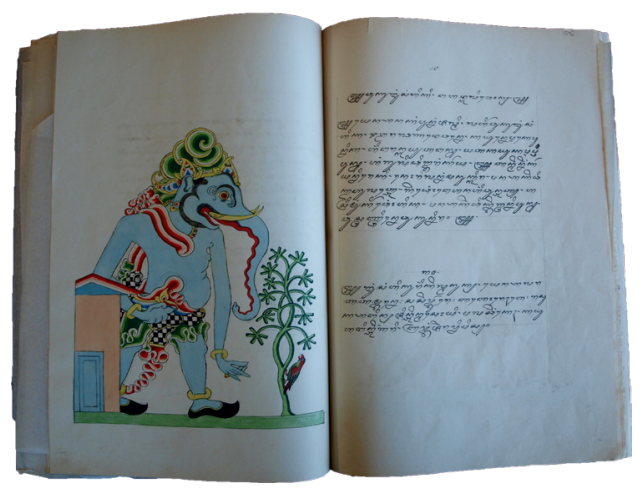

Cod.Or. 6446.

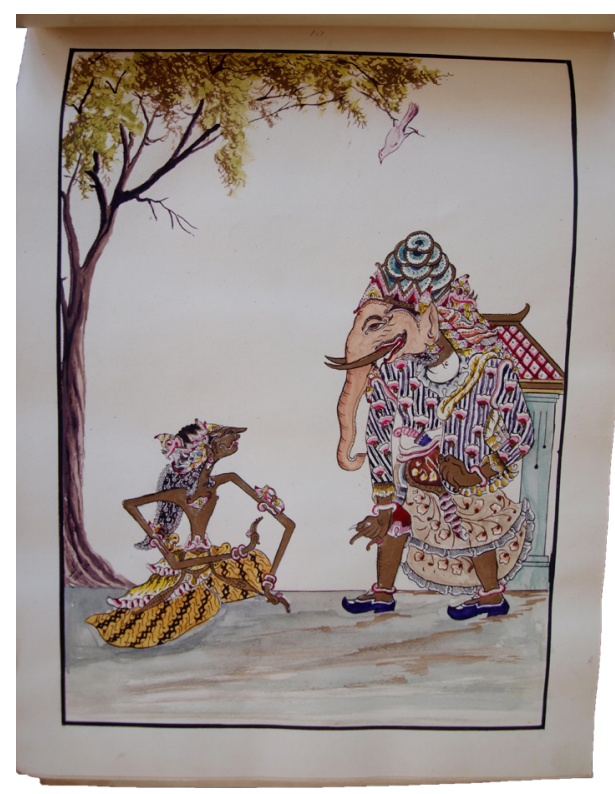

D Or. 410.

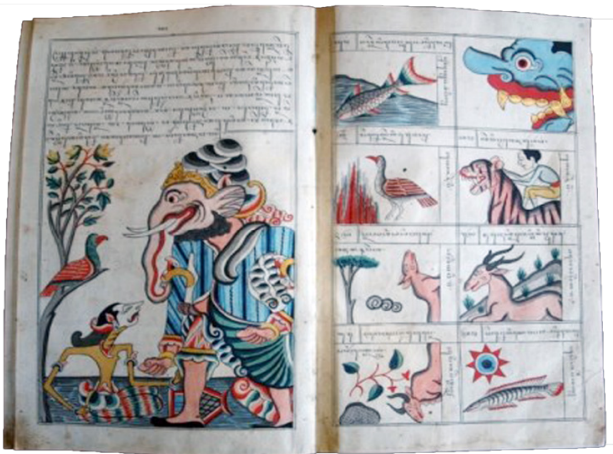

Cod.Or. 12.233.

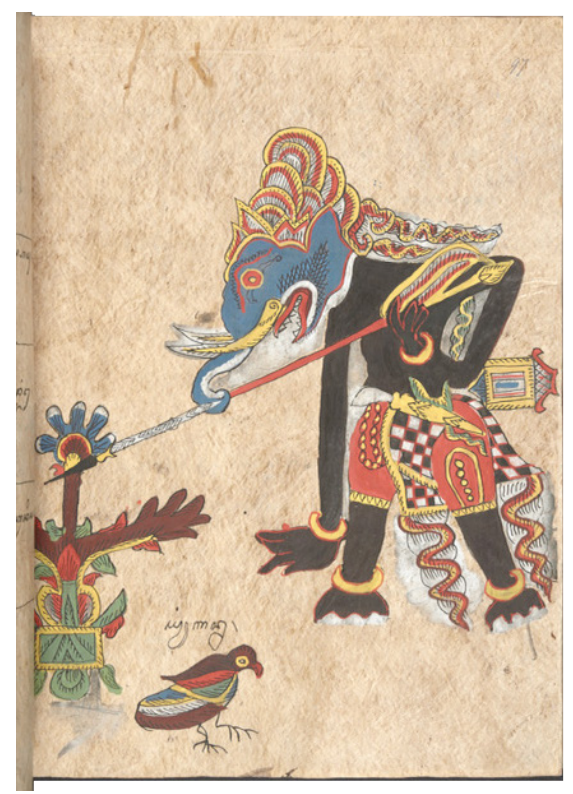

Add MS 12338.

Illustration 25. Gana as portrayed in 6 manuscripts.

God Gana is depicted in many different ways. He is shown either wearing a jacket or with naked torso, with either a crown or a divine turban on his head. Sometimes he is armed with a spear as in Cod.Or. 2230 and Add MS 12338 or with another weapon as in Cod.Or. 6405, but he is often unarmed. Mostly he is depicted standing but he is seated in Ms. or. oct. 4036.

In Ms. or. oct. 4036 (Illustration 26) Gana is portrayed seated before Sungsang and he looks much like an old Javanese statue. The tree is Tangan and the bird is Nori. 


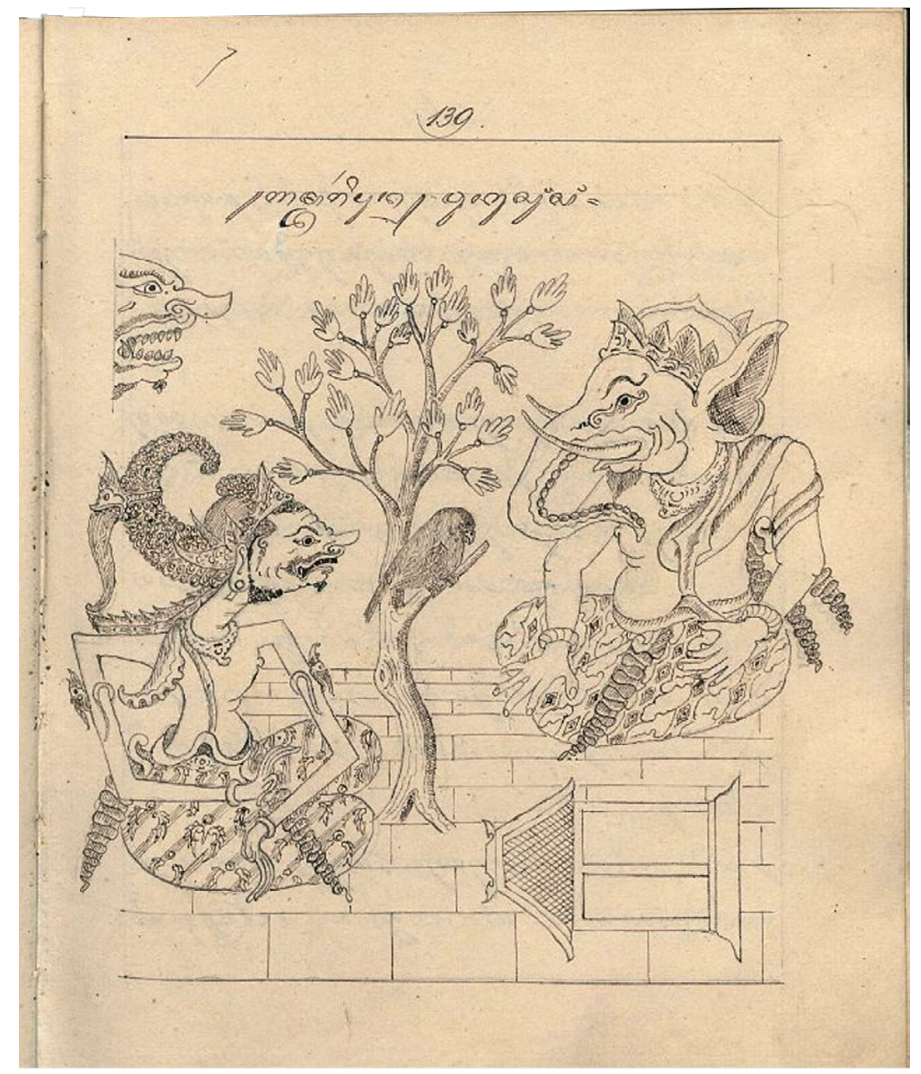

Illustration 26. Gana, the bird Nori, and the tree Tangan. (Ms. or. oct. 4036).

\section{CONCLUSION}

This brief examination of the pawukon manuscripts shows that many differences exist in the wuku elements the illustrations portray, the manner in which they are depicted and the relations these illustrations have with the accompanying text. Furthermore, the way the illustrations and the accompanying texts are placed in relation to each other also varies enormously. Clearly there was no preferred standard for the production of these manuscripts. The differences between the gods mentioned and depicted for specific wukus is especially interesting and could be an indication they were used in a less rigid way in divination. Pawukon manuscripts reveal many variations which might indicate the different individual, regional, social, and temporal backgrounds of the producers and probably also of the commissioners of these manuscripts. Before any definite statements can be made about these features, the codicological, palaeographical and linguistics aspects of the manuscripts have to be explored. The manuscript sample used above is small and the study of a wider sample is essential before a more comprehensive understanding of the features discussed above is possible. 


\section{THE FOLLOWING MANUSCRIPTS HAVE BEEN USED}

LEIDEN UNIVERSITY LIBRARIES:

Cod.Or. 2230, $21 \times 32 \mathrm{~cm}, 210$ pages, prose. Manuscript written in West Javanese script probably from Banten, West Java, or Palembang, Sumatra. The manuscript has 210 pages and some Dutch translations in endeighteenth or early-nineteenth century Dutch idiom. The cover states that the manuscript was written by Pangeran Arya Adikusuma. It was part of the "Collectie Rijksinstelling" which went to Leiden in $1878 .{ }^{34}$

Cod.Or. 6405, $32.5 \times 20.5 \mathrm{~cm}, 85$ pages, prose. Manuscript bought by G.A.J. Hazeu in 1900 from Raden Marta Arjana, Mangkunagaran, Surakarta. ${ }^{35}$

Cod.Or. $6446,33.5 \times 20.5 \mathrm{~cm}, 174$ pages, tembang macapat. Manuscript presented to G.A.J. Hazeu in 1907. The manuscript contains the notes of Tirta Drana, the patih of Purwareja. The pawukon is found on pp. 81-145. ${ }^{36}$

Cod.Or. 12.332, $34 \times 21 \mathrm{~cm}$., 192 pages, prose. Manuscript from Surakarta, purchased from J. de Koning in 1970. It came from the collection of Hendrik Kraemer who bought it in Surakarta in 1930. Pigeaud states that, "It seems likely that the book was written for the use of a lady belonging to the royal family of Surakarta, about the middle of the 19th century" but he does not provide any indication of on what he based his opinion. The pawukon is from pages $1-57 . .^{37}$

D Or. $410,35.5 \times 24.5 \mathrm{~cm}, 30$ pages text in prose and 30 plates. ${ }^{38}$ Manuscript copied around 1957 for R.A. Atma Supana and executed by a member of his staff at the Forestry Department who presented it to W. Bernasco when he left the department and who donated it to the KITLV in 1969. ${ }^{39}$

Cod.Or. 11.650, $21 \times 17 \mathrm{~cm}, 118$ pages, prose. Manuscript copied from a manuscript from Baki, purchased in October 1931 by Hendrik Kraemer. $21 \times 17 \mathrm{~cm}, 118$ pages. ${ }^{40}$

\section{LONDON, BRITISH LIBRARY}

MSS Jav 36, ff 374r-381v, text in tembang macapat. Manuscript in two parts which contains the Babad Mataram and a Babad ing Sangkala and ends with illustrations of 16 wukus. The manuscript is dated AJ $1663=\mathrm{AD} 1738$ and is therefore the oldest manuscript in the sample. There is a note by Mackenzie in pencil on the flyleaf of the first volume which reads, "Djogjakarta MS examined by Mr. Krygsman June 1812". ${ }^{41}$

$34 \quad$ Vreede 1892: 366; Pigeaud 1968: 8, 88.

35 Pigeaud 1968: 369.

36 Pigeaud 1968: 379.

37 Pigeaud 1980: 52-53.

38 While writing this article in Jakarta, I had no access to the Leiden collection and all I had at my disposal were the photographs of the pictures but not of the texts.

39 Pigeaud 1980: 245.

40 Pigeaud 1970: 125.

41 See Ricklefs, Voorhoeve, and Gallop 2014: 62. 
Add MS 12338, ff. 78r-135r, prose. Written on Javanese paper. Ex Crawfurd Collection and written in AD 1807. The manuscript has 29 illustrations of wukus. ${ }^{42}$ It omits the one for the wuku Marakeh.

BL Or 15932, ff. 5v-64r, prose. Papakĕm Pawukon written in AJ 1742 (= AD 18141815 ) and used to belong to Kyai Suradimanggala, Bupati sĕpuh of Dĕmak, in "Bagor" (Bogor) in [AJ] 1742 [AD 1814-15]. The manuscript was found in the British Library in 2003. Another illustrated pawukon manuscript entitled Papakem Watu Gunung by Kyahi Adipati Sura Adimanggala and illustrated by him is IO 2520. I have not been able to establish the relationships between these manuscripts. ${ }^{43}$

BerLin, StaAtsbiblotheK zu BerLin

Berlin Ms. or. oct. 4036, 22 x 18 cm., 592 pages text, pawukon on pages 110199, prose and poetry. Pawukon Manuscript acquired in 1942 (Collection Paardekoper). Compilation of texts on divination, auspicious and inauspicious days proceeded by a Javanese calendar for the years AJ 1819$1882=$ AD 1889-1950. The illustrations in this manuscript are in black and white. The manuscript was made for Mr Paardekoper, Resident of Blora in Central Java, who probably had it made for Dr J. Brandes. ${ }^{44}$

\section{REFERENCES}

Arps, Ben. 1986. Sekar Ageng; Over antieke Javaanse versvormen. Doctoraalscriptie Javaanse Taal- en Letterkunde, Rijksuniversiteit Leiden.

Arps, Bernard. 1992. Tembang in two traditions; Performance and interpretation of Javanese literature. London: School of Oriental and African Studies, University of London.

Clara van Groenendael, Victoria M. 1987. Wayang theatre in Indonesia; An annotated bibliography. Dordrecht/Providence: Foris.

Gallop, Annabel Teh. 2017. "Audiences and an artist", Indonesia and the Malay World 45: 132, 146-178.

Gallop, Annabel The. 2019. "Javanese manuscripts in the Mackenzie collection: the publication of Whatherbee's 'Inventory'”. [Https:/ /blogs.bl.uk/asianand-african/2019/01/javanese-manuscripts-in-the-mackenzie-collectionthe-publication-of-weatherbees-inventory.html.]

Kumar, Ann. 1996. Java and modern Europe; Ambiguous encounters. Richmond: Curzon.

Kumar, Ann. 2009/2011. "Significant time, myths and power in the Javanese calendar", in: Jan van der Putten and Mary Kilcline Cody (eds), Lost times and unfold tales from the Malay World, pp. 77-99. Singapore: NUS Press.

Kumar, Ann. 2018. Pawukon; Javanese calendrical manuscripts. [Https:// blogs.bl.uk/asian-and-african/2018/11/pawukon-javanese-calendrical-

42 Ricklefs, Voorhoeve, and Gallop 2014: 52

43 See Ricklefs, Voorhoeve, and Gallop 2014: 68, 284-285.

44 Pudjiastuti and Hanstein 2016: 199. 
manuscripts.html?utm_source=feedburner\&utm_medium=email\&utm_ campaign $=$ Feed $\% 3 \mathrm{~A}+$ asian-and-african $+\% 28$ Asia + and + Africa $\% 29$.]

Kumar, Ann and John H. McGlynn. 1996. Illuminations; The writing traditions of Indonesia; Featuring manuscripts from the National Library of Indonesia. Jakarta: The Lontar Foundation; New York / Tokyo: Weatherhill, Inc.

Meij, Dick van der. 2017. Indonesian manuscripts from the Islands of Java, Madura, Bali and Lombok. Leiden: Brill. [Handbuch der Orientalistik 3-24.]

Miyazaki, Koji. 2018. "Javanese calendar and myth; Wuku and the story of Watu gunung", in: Yumi Sugahara and Willem van der Molen (eds), Transformations of Religions as reflected in Javanese texts, pp. 54-76. Tokyo: Research Institute for Languages and Cultures of Asia and Africa, Tokyo University of Foreign Studies. [Contributions to the Study of Javanese Literature, Culture and History 5.]

Mulyono, Djoko. 1993. Kalender pawukon 200 tahun; The 200-year pawukon calendar. N.p.: Studio Delapanpuluh Enterprise.

Pigeaud, Theodore G.Th. 1968. Literature of Java; Catalogue raisonné of Javanese manuscripts in the Library of the University of Leiden and other public collections in the Netherlands by Theodore G.Th. Pigeaud. Volume II: Descriptive lists of Javanese manuscripts. Leiden: In Bibliotheca Universitatis Lugduni Batavorum. [Codices Manuscripti X.]

Pigeaud, Theodore G.Th. 1970. Literature of Java; Catalogue Raisonné of Javanese manuscripts in the Library of the University of Leiden and other public collections in the Netherlands by Theodore G.Th. Pigeaud. Volume III Illustrations and Facsimiles of Manuscripts, Maps, Addenda and a General Index of Names and Subjects. Leiden: In Bibliotheca Universitatis Lugduni Batavorum. [Codices Manuscripti XI.]

Pigeaud, Theodore G.Th. 1980. Literature of Java; Catalogue raisonné of Javanese manuscripts in the Library of the University of Leiden and other public collections in the Netherlands by Theodore G.Th. Pigeaud. Volume IV: Supplement. Leiden: In Bibliotheca Universitatis Lugduni Batavorum. [Codices Manuscripti XX.]

Pudjiastuti, Titik and Thoralf Hanstein (eds). 2016. Catalogue of Indonesian Manuscripts. Collection Staatsbibliothek zu Berlin Preußischer Kulturbesitz. Bali, Java, Kalimantan, Lombok, Madura, Sulawesi, Sumatra, Sumbawa. Jakarta: Museum Nasional.

Ricklefs, M.C. 1978. Modern Javanese historical tradition; A study of an original Kartasura chronicle and related materials. London: School of Oriental and African Studies, University of London.

Ricklefs, M.C., P. Voorhoeve, and Annabel Teh Gallop. 2014. Indonesian manuscripts in Great Britain; A catalogue of manuscripts in Indonesian languages in British public collections. New edition with addenda and corrigenda. Jakarta: Ecole française d'Extrême Orient/Perpustakaan Republik Indonesia/Yayasan Pustaka Obor Indonesia.

Vreede, A.C. 1892. Catalogus van de Javaansche en Madoereesche handschriften der Leidsche Universiteits-bibliotheek. Leiden: Brill. 
Weatherbee, Donald E. 1978. “Raffles' sources for traditional Javanese historiography and the Mackenzie collections", Indonesia No. 26: 63-94.

Wilpert, Clara B. 1980. Götter und Dämonen; Handschrift mit Schattenspielfiguren, Mit einer Einführung in das javanische Schattenspiel. Harenberg: Die Bibliophilen Taschenbücher. 


\begin{tabular}{|c|c|c|}
\hline \multicolumn{3}{|c|}{ THE WUKUS AND THEIR GODS, TREES, BIRDS } \\
\hline 1. SINTA ${ }^{45}$ & 11. GALUNGAN & $\begin{array}{l}\text { 21. MAKTAL, MATAL (Cod. } \\
\text { Or. 2230) }\end{array}$ \\
\hline $\begin{array}{l}\text { God: } \\
\text { Yamadipati/Yama } \\
\text { Cod.Or. 6405, 11.650, } \\
\text { 12.332, Berlin Ms. or. oct. } \\
\text { 4036, MSS Jav 36, Add } \\
\text { MS 12338, BL Or15932 }\end{array}$ & $\begin{array}{l}\text { God: } \\
\text { Wisnu } \\
\text { Cod.Or. } 2230 \\
\text { Kumajaya/Kamajaya/ } \\
\text { Komajaya } \\
\text { Cod.Or. 6405, 6446, } \\
\text { 11.650, 12.332, Berlin Ms. } \\
\text { or. oct. 4036, Add MS } \\
\text { 12338, , BL Or } 15932 \\
\text { Dhewa } \\
\text { MSS Jav } 36\end{array}$ & $\begin{array}{l}\text { God: } \\
\text { Siwah } \\
\text { Cod.Or. } 2230 \\
\text { Sakri } \\
\text { Cod.Or. } 6405,11.650 \text {, } \\
\text { 12.332, Berlin Ms. or. oct. } \\
\text { 4036, Add MS 12338 } \\
\text { Cakra } \\
\text { Cod.Or. } 6446 \\
\text { Condrasa } \\
\text { BL Or } 15932\end{array}$ \\
\hline $\begin{array}{l}\text { Tree: } \\
\text { Gendhayakan } \\
\text { Cod.Or. 6405, 11.650, } \\
\text { 12.332, Berlin Ms. or. oct. } \\
\text { 4036, Add MS 12338, BL } \\
\text { Or 15932 } \\
\text { Not mentioned MSS Jav } \\
36\end{array}$ & $\begin{array}{l}\text { Tree: } \\
\text { Wijayakusuma } \\
\text { Cod.Or. } 2230 \\
\text { Tangan } \\
\text { Cod.Or. 6405, 6446, } \\
\text { 11.650, 12.332, Berlin Ms. } \\
\text { or. oct. 4036, MSS Jav 36, } \\
\text { Add MS 12338, BL Or } \\
15932\end{array}$ & $\begin{array}{l}\text { Tree: } \\
\text { Nagasari } \\
\text { Cod.Or. 2230, 6405, 6446, } \\
\text { 11.650, 12.332, Berlin Ms. } \\
\text { or. oct. 4036, Add MS } \\
\text { 12338, BL Or } 15932\end{array}$ \\
\hline $\begin{array}{l}\text { Bird: } \\
\text { Gagak } \\
\text { Cod.Or. 6405, 11.650, } \\
\text { 12332, Berlin Ms. or. oct. } \\
\text { 4036, MSS Jav 36, Add } \\
\text { MS 12338, BL Or } 15932\end{array}$ & $\begin{array}{l}\text { Bird: } \\
\text { Bi(bi)dho/Babidho/ } \\
\text { Bebidho/Kabidho } \\
\text { Cod.Or. 2230, 6405, } 6446 . \\
\text { 11.650, 12.332, Berlin Ms. } \\
\text { or. oct. 4036, MSS Jav 36, } \\
\text { Add MS 12338, BL Or } \\
15932\end{array}$ & $\begin{array}{l}\text { Bird: } \\
\text { Ayam Alas }{ }^{46} \text { /Satawana/ } \\
\text { Sawungwana } \\
\text { Cod.Or. 2230, 6405, 6446, } \\
\text { 11.650, 12.332, Berlin Ms. } \\
\text { or. oct. 4036, Add MS } \\
\text { 12338, BL Or } 15932\end{array}$ \\
\hline 2. LANDEP & 12. KUNINGAN & 22. WUYE \\
\hline $\begin{array}{l}\text { God: } \\
\text { Kuwera } \\
\text { Cod.Or. } 2230 \\
\text { Mahadewa } \\
\text { Cod.Or. 6405, 6446, 11.650, } \\
\text { 12.332, Berlin Ms. or. oct. } \\
\text { 4036, MSS Jav 36, Add MS } \\
12338^{47} \\
\text { Surya } \\
\text { BL Or } 15932\end{array}$ & $\begin{array}{l}\text { God: } \\
\text { Uma Cod.Or. 2230, Add } \\
\text { MS } 12338 \\
\text { Endra } \\
\text { Cod.Or. } 6405,6446,11.650, \\
\text { 12.332, Berlin Ms. or. oct. } \\
\text { 4036, MSS Jav 36, BL Or } \\
15932\end{array}$ & $\begin{array}{l}\text { God: } \\
\text { Poncaresi } \\
\text { Cod.Or. } 2230 \\
\text { Kuwera/Kawera/Wera } \\
\text { Cod.Or. 6405, 6446, 11.650, } \\
\text { 12.332, Berlin Ms. or. oct. } \\
\text { 4036, Add MS 12338, BL } \\
\text { Or 15932 }\end{array}$ \\
\hline
\end{tabular}

45 No mention of a tree in the text in Cod.Or. 2230 but the forest roosted is included in the illustration.

46 In the illustration called Hyang Baruna. 


\begin{tabular}{|c|c|c|}
\hline $\begin{array}{l}\text { Tree: } \\
\text { Gendhayakan/ } \\
\text { Kendayakan } \\
\text { Cod.Or. 2230, 6405, 6446, } \\
\text { 11.650, 12.332, Berlin Ms. } \\
\text { or. oct. 4036, MSS Jav 36, } \\
\text { Add MS 12338, BL Or } \\
15932\end{array}$ & $\begin{array}{l}\text { Tree: } \\
\text { Wijayamulya/ } \\
\text { (Wi)jayakusuma, } \\
\text { Resmiwijayakusuma } \\
\text { Cod.Or. 2230, } 6405 \text { 6446, } \\
\text { 11.650, 12.332, Berlin Ms. } \\
\text { or. oct. 4036, MSS Jav 36, } \\
\text { Add MS 12338, BL Or } \\
15932\end{array}$ & $\begin{array}{l}\text { Tree: } \\
\text { Tal } \\
\text { Cod.Or. 2230, 6405, 6446, } \\
\text { 11.650, 12.332, Berlin Ms. } \\
\text { or. oct. 4036, Add MS } \\
\text { 12338 } \\
\text { Siwalan } \\
\text { BL Or 15932 }\end{array}$ \\
\hline $\begin{array}{l}\text { Bird: } \\
\text { Atat (Kembang) } \\
\text { Cod.Or. 2230, Cod.Or. } \\
\text { 6405, 11.650, 12.332, MSS } \\
\text { Jav 36, Add MS 12338, BL } \\
\text { Or 15932 Berlin Ms. or. } \\
\text { oct. } 4036 \\
\text { Nori/Nari } \\
\text { Cod.Or. } 6446\end{array}$ & $\begin{array}{l}\text { Bird: } \\
\text { Urang-urangan/Rang- } \\
\text { urangan (BL Or 15932) } \\
\text { Cod.Or. 2230, 6405, 6446, } \\
\text { 11.650, 12.332, Berlin Ms. } \\
\text { or. oct. 4036, MSS Jav 36, } \\
\text { Add MS 12338, BL Or } \\
15932\end{array}$ & $\begin{array}{l}\text { Bird: } \\
\text { Terik } \\
\text { Cod.Or. } 2230 \\
\text { (Ka)podhang } \\
\text { Cod.Or. } 64056446 \text {, Add } \\
\text { MS 12338, BL Or } 15932 \\
\text { Gogik } \\
\text { Cod.Or. 11.650, 12.332, } \\
\text { Berlin Ms. or. oct. } 4036\end{array}$ \\
\hline $\begin{array}{l}\text { 3. WuKIR } \\
\text { God: } \\
\text { Baruna } \\
\text { Cod.Or. } 2230 \\
\text { Mahayekti } \\
\text { Cod.Or. 6405, 6446, } \\
\text { 11.650, 12.332, Berlin Ms. } \\
\text { or. oct. } 4036 \\
\text { Kuwera } \\
\text { Add MS } 12338 \\
\text { Asmara } \\
\text { BL Or } 15932 \\
\text { Mayaseka } \\
\text { MSS Jav } 36\end{array}$ & $\begin{array}{l}\text { 13. LANGKIR } \\
\text { God: } \\
\text { Poncadriya } \\
\text { Cod.Or. } 2230 \\
\text { Kala } \\
\text { Cod.Or. 6405, 6446, } \\
\text { 11.650, 12.332, Berlin Ms. } \\
\text { or. oct. 4036, MSS Jav 36, } \\
\text { Add MS 12338, BL Or } \\
15932\end{array}$ & $\begin{array}{l}\text { 23. MANAHIL } \\
\text { God: } \\
\text { Citragotra/Citragota/ } \\
\text { Citragatra } \\
\text { Cod.Or. 2230, 6405, 6446, } \\
\text { 11.650, 12.332, Berlin Ms. } \\
\text { or. oct. 4036, Add MS } \\
\text { 12338, BL Or 15932 }\end{array}$ \\
\hline $\begin{array}{l}\text { Tree: } \\
\text { Nagasari } \\
\text { Cod.Or. 2230, 6405, 6446, } \\
\text { 11.650, 12.332, Berlin Ms. } \\
\text { or. oct. 4036, MSS Jav 36, } \\
\text { Add MS 12338, BL Or } \\
15932\end{array}$ & $\begin{array}{l}\text { Tree: } \\
\text { Ingas } \\
\text { Cod.Or. 2230, } 6446 \\
\text { Ingas and Cemara(sol) } \\
\text { Cod.Or. 11.650, }{ }^{48} 12.332, \\
\text { Berlin Ms. or. oct. 4036, } \\
\text { Add MS 12338, BL Or } \\
15932 \\
\text { No tree } \\
\text { MSS Jav } 36\end{array}$ & $\begin{array}{l}\text { Tree: } \\
\text { Tigaron/Tegaron } \\
\text { Cod.Or. 2230, } 6405 \text { 6446, } \\
\text { 11.650, Berlin Ms. or. oct. } \\
\text { 4036, Add MS 12338, BL } \\
\text { Or 15932 } \\
\text { Garu } \\
\text { Cod.Or. } 12.332\end{array}$ \\
\hline
\end{tabular}

47 Kala sarta nyokok baune gedhe Cod.Or. 11.650 and Kala anyokot baune gedhe Berlin Ms. or. oct. 4036. 


\begin{tabular}{|c|c|c|}
\hline $\begin{array}{l}\text { Bird: } \\
\text { Manyar } \\
\text { Cod.Or. 2230, 6405, 6446, } \\
\text { 11.650, 12.332, Berlin Ms. } \\
\text { or. oct. 4036, MSS Jav 36, } \\
\text { Add MS 12338, BL Or } \\
15932\end{array}$ & $\begin{array}{l}\text { Bird: } \\
\text { Gemeg/Gemag/Gemak } \\
\text { Cod.Or. 2230, 6405, 6446, } \\
\text { 11.650, 12.332, Berlin Ms. } \\
\text { or. oct. 4036, MSS Jav 36, } \\
\text { Add MS 12338, BL Or } \\
15932\end{array}$ & $\begin{array}{l}\text { Bird: } \\
\text { Sepah, Se(se)pah(an) } \\
\text { Cod.Or. 2230, 6405, 6446, } \\
\text { 11.650, 12.332, Berlin Ms. } \\
\text { or. oct. 4036, Add MS } \\
\text { 12338, BL Or } 15932\end{array}$ \\
\hline $\begin{array}{l}\text { 4. KURANTIL } \\
\text { God: } \\
\text { Purusangkara } \\
\text { Cod.Or. 2230, Add MS } \\
\text { 12338, BL Or 15932 } \\
\text { Langsur/Lasur } \\
\text { Cod.Or. 6405, 6446, 11.650, } \\
\text { 12.332, MSS Jav 36, Berlin } \\
\text { Ms. or. oct. } 4036\end{array}$ & $\begin{array}{l}\text { 14. MONDHASIYA } \\
\text { God: } \\
\text { Durga } \\
\text { Cod.Or. } 2230 \\
\text { Bra(h)ma/Berama } \\
\text { Cod.Or. 6405, 6446, 12.332, } \\
\text { Berlin Ms. or. oct. 4036, } \\
\text { MSS Jav 36, Add MS12338, } \\
\text { BL Or 15932 }\end{array}$ & $\begin{array}{l}\text { 24. PRANGBAKAT } \\
\text { God: } \\
\text { Bimasekti } \\
\text { Cod.Or. } 2230 \\
\text { Bima } \\
\text { Cod.Or. } 6405 \\
\text { Bisma } \\
\text { Cod.Or. } 6446,11.650 \text {, } \\
\text { 12.332, Berlin Ms. or. oct. } \\
\text { 4036, BL Or } 15932 \\
\text { Bayu } \\
\text { Add MS } 12338\end{array}$ \\
\hline $\begin{array}{l}\text { Tree: } \\
\text { Tangan } \\
\text { Cod.Or. 2230, 6405 6446, } \\
\text { Add MS 12338, BL Or } \\
15932 \\
\text { Ingas } \\
\text { Cod.Or. 11.650, 12.332, } \\
\text { Berlin Ms. or. oct. } 4036 \\
\text { Not mentioned } \\
\text { MSS Jav 36, }\end{array}$ & $\begin{array}{l}\text { Tree: } \\
\text { Asem } \\
\text { Cod.Or. 2230, 6405, Berlin } \\
\text { Ms. or. oct. 4036, MSS Jav } \\
\text { 36, Add MS 12338, BL Or } \\
\text { 15932 } \\
\text { Kamal } \\
\text { Cod.Or. 6446 Sinom } \\
\text { Cod.Or. 11.650, 12.332 }\end{array}$ & $\begin{array}{l}\text { Tree: } \\
\text { Tirisan } \\
\text { Cod.Or. 2230, 11.650, } \\
\text { 12.332, Berlin Ms. or. oct. } \\
\text { 4036, Add MS 12338 } \\
\text { Waringing (Gedhe) } \\
\text { Cod.Or. 6446, BL Or } 15932\end{array}$ \\
\hline $\begin{array}{l}\text { Bird: } \\
\text { Sulindhit/Slindhit } \\
\text { Cod.Or. 2230, MSS Jav 36, } \\
\text { Salindhit(an) } \\
\text { Cod.Or. 6405, 6446, 11.650, } \\
\text { 12.332, Berlin Ms. or. oct. } \\
\text { 4036, Add MS 12338, BL } \\
\text { Or } 15932\end{array}$ & $\begin{array}{l}\text { Bird: } \\
\text { Palathuk (Bawang) } \\
\text { Cod.Or. 2230, 6405, 6446, } \\
\text { 11.650, 12.332, Berlin Ms. } \\
\text { or. oct. 4036, MSS Jav 36, } \\
\text { Add MS 12338, BL Or } \\
15932\end{array}$ & $\begin{array}{l}\text { Bird: } \\
\text { Tengkek } \\
\text { Cod.Or. } 2230 \\
\text { Urang-urangan/Rang- } \\
\text { urangan } \\
\text { Cod.Or. 6405, 6446, Add } \\
\text { MS 12338, BL Or 15932 } \\
\text { Garuda(yeksa) } \\
\text { Cod.Or. 11.650, 12.332, } \\
\text { Berlin Ms. or. oct. } 4036\end{array}$ \\
\hline $\begin{array}{l}\text { 5. TOLU, TALU (COD.Or. } \\
\text { 2230, BL Or 15932) }\end{array}$ & 15. Julung Pujut & 25. BALA \\
\hline $\begin{array}{l}\text { God: } \\
\text { Brama } \\
\text { Cod.Or. 2230, Add MS } \\
12338\end{array}$ & $\begin{array}{l}\text { God:, } \\
\text { (M)aheswara } \\
\text { Cod.Or. } 2230 \text { M, Add MS } \\
12338\end{array}$ & $\begin{array}{l}\text { God: } \\
\text { Cingkaramongga Udhuta } \\
\text { Cod.Or. } 2230\end{array}$ \\
\hline
\end{tabular}




\begin{tabular}{|c|c|c|}
\hline $\begin{array}{l}\text { Bayu } \\
\text { Cod.Or. } 6405,6446,11.650, \\
\text { 12.332, Berlin Ms. or. oct. } \\
\text { 4036, BL Or } 15932\end{array}$ & $\begin{array}{l}\text { Guretna/Guritna } \\
\text { Cod.Or. 6405, 11.650, } \\
\text { 12.332, Berlin Ms. or. oct. } \\
\text { 4036, MSS Jav } 36 \\
\text { Poncaresmi }\end{array}$ & $\begin{array}{l}\text { Durga } \\
\text { Cod.Or. 6405, 6446, 11.650, } \\
\text { 12.332, Berlin Ms. or. oct. } \\
\text { 4036, Add MS 12338, BL } \\
\text { Or } 15932\end{array}$ \\
\hline $\begin{array}{l}\text { Tree: } \\
\text { Walikukun } \\
\text { Cod.Or. 2230, 6405 6446, } \\
\text { Add MS 12338, BL Or } \\
15932 \\
\text { Garu } \\
\text { Cod.Or. 11.650, 12.332, } \\
\text { Berlin Ms. or. oct. } 4036\end{array}$ & $\begin{array}{l}\text { Tree: } \\
\text { Rambutan } \\
\text { Cod.Or. } 2230 \\
\text { Arembuyuk/Rembuyuk/ } \\
\text { Rembuyug } \\
\text { Cod.Or. 6405, 6446, 12.332, } \\
\text { Berlin Ms. or. oct. 4036, BL } \\
\text { Or } 15932 \\
\text { Rembuyun } \\
\text { Cod.Or. 11.650 } \\
\text { Rembuyut/Rabayut } \\
\text { MSS Jav 36, Add MS12338 }\end{array}$ & $\begin{array}{l}\text { Tree: }{ }^{49} \\
\text { Cemara } \\
\text { Cod.Or. 2230, 6405, 11.650, } \\
\text { 12.332, Berlin Ms. or. oct. } \\
\text { 4036, Add MS 12338 } \\
\text { No tree } \\
\text { BL Or } 15932\end{array}$ \\
\hline $\begin{array}{l}\text { Bird: } \\
\text { Beranjangan } \\
\text { Cod.Or. 2230, 6405, 6446, } \\
\text { 11.650, 12.332, Berlin Ms. } \\
\text { or. oct. 4036, Add MS } \\
\text { 12338, BL Or } 15932\end{array}$ & $\begin{array}{l}\text { Bird: } \\
\text { Prisowan } \\
\text { Cod.Or. 2230, MSS Jav 36, } \\
\text { BL Or 15932 } \\
\text { Prit Johan } \\
\text { Cod.Or. 6405, Berlin Ms. } \\
\text { or. oct. } 4036 \\
\text { Mricawa? } \\
\text { Cod.Or. } 6446 \\
\text { Johan } \\
\text { Cod.Or. 11.650, } 12.332 \\
\text { Prit Bawang } \\
\text { Add MS 12338 }\end{array}$ & $\begin{array}{l}\text { Bird: } \\
\text { Ayam Alas/Satawana/ } \\
\text { Sawungwana } \\
\text { Cod.Or. 2230, 6405, 6446, } \\
\text { 11.650, 12.332, Berlin Ms. } \\
\text { or. oct. 4036, Add MS } \\
\text { 12338, BL Or 15932 }\end{array}$ \\
\hline $\begin{array}{l}\text { 6. GUMBREG } \\
\text { God: } \\
\text { Kumara? } \\
\text { Cod.Or. } 2230 \\
\text { Condra } \\
\text { Cod.Or. } 6405 \\
\text { Cakra/Sakra } \\
\text { Cod.Or. 6446, } 11.650 \text {, } \\
\text { 12.332, Berlin Ms. or. oct. } \\
\text { 4036, Add MS 12338, }{ }^{50} \text { BL } \\
\text { Or 15932 }\end{array}$ & $\begin{array}{l}\text { 16. PAHANG } \\
\text { God: } \\
\text { Bayu/Kurena } \\
\text { Cod.Or. 2230, Add MS } \\
\text { 12338 } \\
\text { (We)tontra } \\
\text { Cod.Or. 6405, 6446, 11.650, } \\
\text { 12.332, Berlin Ms. or. oct. } \\
\text { 4036, MSS Jav 36, BL Or } \\
\text { 15932 }\end{array}$ & $\begin{array}{l}\text { 26. Wugu } \\
\text { God: } \\
\text { Srigati } \\
\text { Cod.Or. } 2230 \\
\text { Singajalma/Jalma } \\
\text { Cod.Or. 6405, 6446, 11.650, } \\
\text { 12.332, Berlin Ms. or. oct. } \\
\text { 4036, Add MS 12338 } \\
\text { Lodra } \\
\text { BL Or } 15932\end{array}$ \\
\hline
\end{tabular}

48 No tree mentioned for this wuku in Cod.Or. 6446.

49 But in the drawing called Gonakumara

50 In illustration named Kuretna 


\begin{tabular}{|c|c|c|}
\hline $\begin{array}{l}\text { Tree: } \\
\text { Waringin } \\
\text { Cod.Or. 2230, 6446, 11.650, } \\
\text { 12.332, Berlin Ms. or. oct. } \\
\text { 4036, Add MS 12338, BL } \\
\text { Or 15932 } \\
\text { Mandera } \\
\text { Cod.Or. } 6405\end{array}$ & $\begin{array}{l}\text { Tree: } \\
\text { Gendhayakan } \\
\text { Cod.Or. 2230, 6405, 6446, } \\
\text { 11.650, 12.332, Berlin Ms. } \\
\text { or. oct. 4036, MSS Jav 36, } \\
\text { BL Or 15932 } \\
\text { Rembuyut } \\
\text { Add MS } 12338\end{array}$ & $\begin{array}{l}\text { Tree: } \\
\text { Kuldi } \\
\text { Cod.Or. } 2230 \\
\text { Wuni } \\
\text { Cod.Or. 6405, 6446, } \\
\text { 11.650, 12.332, Berlin Ms. } \\
\text { or. oct. 4036, Add MS } \\
\text { 12338, BL Or } 15932\end{array}$ \\
\hline $\begin{array}{l}\text { Bird: }^{52} \\
\text { Ayam Alas/Satawana/ } \\
\text { Sawungwana } \\
\text { Cod.Or. 2230, 6405, } 6446 \\
\text { 11.650, 12.332, Berlin Ms. } \\
\text { or. oct. 4036, Add MS } \\
\text { 12338, BL Or } 15932\end{array}$ & $\begin{array}{l}\text { Bird: } \\
\text { Manyar } \\
\text { Cod.Or. } 2230 \\
\text { Cocak/Cucak } \\
\text { Cod.Or. 6405, 6446, 11.650, } \\
\text { MSS Jav 36, BL Or 15932 } \\
\text { Johan } \\
\text { Cod.Or. } 12.332 \\
\text { Cowan } \\
\text { Berlin Ms. or. oct. } 4036 \\
\text { Pricowan } \\
\text { Add MS } 12338\end{array}$ & $\begin{array}{l}\text { Bird: } \\
\text { (Ka)podhang } \\
\text { Cod.Or. 2230, 6405, 6446, } \\
\text { 11.650, 12.332, Berlin Ms. } \\
\text { or. oct. 4036, Add MS } \\
\text { 12338, BL Or 15932 }\end{array}$ \\
\hline $\begin{array}{l}\text { 7. WARIGA (ALIT) } \\
\text { God: } \\
\text { Kamajaya } \\
\text { Cod.Or. } 2230 \\
\text { Asmara } \\
\text { Cod.Or. 6405, 6446, } \\
\text { 11.650, 12.332, Berlin Ms. } \\
\text { or. oct. 4036, MSS Jav 36, } \\
\text { Add MS 12338,53 BL Or } \\
15932\end{array}$ & $\begin{array}{l}\text { 17. KURUWELUT } \\
\text { God: } \\
\text { Kuretna } \\
\text { Cod.Or. } 2230 \\
\text { Wisnu/Wesnu/Waresnu } \\
\text { Cod.Or. 6405, 6446, } \\
\text { 11.650, }{ }^{4} \text { 12.332, Berlin } \\
\text { Ms. or. oct. 4036, MSS Jav } \\
\text { 36, Add MS 12338, BL Or } \\
\text { 15932 }\end{array}$ & $\begin{array}{l}\text { 27. WAYANG }{ }^{55} \\
\text { God: } \\
\text { Kala } \\
\text { Cod.Or. } 2230 \\
\text { Sri } \\
\text { Cod.Or. 6446, 11.650, } \\
\text { 12.332, Berlin Ms. or. oct. } \\
\text { 4036, Add MS 12338, BL } \\
\text { Or 15932 }\end{array}$ \\
\hline $\begin{array}{l}\text { Tree: } \\
\text { Pelas/Rempelas } \\
\text { Cod.Or. 2230, } 6405 \text { Cod. } \\
\text { Or. 6446 Sulastri } \\
\text { Cod.Or. 11.650, 12.332, } \\
\text { Berlin Ms. or. oct. 4036, } \\
\text { MSS Jav 36, Add MS } \\
\text { 12338, BL Or } 15932\end{array}$ & $\begin{array}{l}\text { Tree: } \\
\text { Parijatha } \\
\text { Cod.Or. 2230, 6405, 6446, } \\
\text { 11.650, 12.332, Berlin Ms. } \\
\text { or. oct. 4036, MSS Jav 36, } \\
\text { Add MS 12338, BL Or } \\
15932\end{array}$ & $\begin{array}{l}\text { Tree: } \\
\text { Ce(m)paka/Campaka } \\
\text { Cod.Or. 2230, 6446, } \\
\text { 11.650, 12.332, Berlin Ms. } \\
\text { or. oct. 4036, Add MS } \\
\text { 12338, BL Or } 15932\end{array}$ \\
\hline
\end{tabular}

51 No bird mentioned in the text of Add MS 12338 but in the drawing an ayam alas.

52 In the illustration called Gonakumara.

53 Wisnu amandhi cakra Cod.Or. 11.650

54 No information from Cod.Or. 6405. 


\begin{tabular}{|c|c|c|}
\hline $\begin{array}{l}\text { Bird: } \\
\text { Kuntul Putih } \\
\text { Cod.Or. } 2230 \\
\text { (Ka)podhang } \\
\text { Cod.Or. 6405, 6446, } \\
\text { 11.650, 12.332, Berlin Ms. } \\
\text { or. oct. 4036, MSS Jav 36, } \\
\text { Add MS 12338, BL Or } \\
15932\end{array}$ & $\begin{array}{l}\text { Bird: } \\
\text { Se(Se)pahan } \\
\text { Cod.Or. 2230, 6405, 6446, } \\
\text { 11.650, 12.332, Berlin Ms. } \\
\text { or. oct. 4036, MSS Jav 36, } \\
\text { Add MS 12338, BL Or } \\
15932\end{array}$ & $\begin{array}{l}\text { Bird: } \\
\text { Ayam Alas/ } \\
\text { Sawungwana } \\
\text { Cod.Or. 2230, 6446, } \\
\text { 11.650, 12.332, Berlin Ms. } \\
\text { or. oct. 4036, Add MS } \\
\text { 12338, BL Or 15932 }\end{array}$ \\
\hline $\begin{array}{l}\text { 8. WARIGA GUNG/ } \\
\text { WARIGAJAR (BL Or 15932) }\end{array}$ & 18. MARAKEH & 28. KuLAWU \\
\hline $\begin{array}{l}\text { God: } \\
\text { Yamadipati } \\
\text { Cod.Or. } 2230 \\
\text { Poncares(m)i } \\
\text { Cod.Or. 6405, 6446, MSS } \\
\text { Jav 36, Add MS 12338, BL } \\
\text { Or 15932 } \\
\text { Maharesi } \\
\text { Cod.Or. 11.650, 12.332, } \\
\text { Berlin Ms. or. oct. } 4036\end{array}$ & $\begin{array}{l}\text { God: } \\
\text { Penyarikan } \\
\text { Cod.Or. } 2230 \\
\text { (Sureng)gana/ } \\
\text { Suronggana } \\
\text { Cod.Or. 6405, 6446, } \\
\text { 11.650, 12.332, Berlin Ms. } \\
\text { or. oct. 4036, MSS Jav 36, } \\
\text { Add MS 12338, BL Or } \\
15932\end{array}$ & $\begin{array}{l}\text { God: } \\
\text { Gana } \\
\text { Cod.Or. } 2230 \\
\text { Sedana57 } \\
\text { Cod.Or. 6405, 11.650, } \\
\text { Berlin Ms. or. oct. } 4036 \\
\text { Syandana } \\
\text { Cod.Or. } \\
\text { Sentana } \\
\text { Cod.Or 12.332 } \\
\text { Darmaraja } \\
\text { Add MS } 12338 \\
\text { Suwandana } \\
\text { BL Or } 15932\end{array}$ \\
\hline $\begin{array}{l}\text { Tree: } \\
\text { Cemara } \\
\text { Cod.Or. 2230, 6446, } \\
\text { 11.650, 12.332, Berlin Ms. } \\
\text { or. oct. 4036, BL Or } 15932 \\
\text { Cepaka } \\
\text { Cod.Or. 6405, Add MS } \\
\text { 12338 } \\
\text { (Na)gasari } \\
\text { MSS Jav } 36\end{array}$ & $\begin{array}{l}\text { Tree: } \\
\text { Trenggulun } \\
\text { Cod.Or. } 2230 \text { 11.650, } \\
\text { Trengguli } \\
\text { Cod.Or. 6405, Berlin Ms. } \\
\text { or. oct. 4036, Add MS } \\
12338 \\
\text { Tangguli } \\
\text { Cod.Or. 6446, MSS Jav 36, } \\
\text { BL Or 15932 } \\
\text { Tergulun } \\
\text { Cod.Or. } 12.332\end{array}$ & $\begin{array}{l}\text { Tree: } \\
\text { Wungli } \\
\text { Cod.Or. } 2230 \\
\text { Tal/Talkadha } \\
\text { Cod.Or 6405, 11.650, } \\
\text { 12.332, Berlin Ms. or. oct. } \\
\text { 4036, Add MS } 12338 \\
\text { Siwalan } \\
\text { Cod.Or. 6446, BL Or } \\
15932\end{array}$ \\
\hline $\begin{array}{l}\text { Bird: } \\
\text { Betet } \\
\text { Cod.Or. 2230, 6405, 6446, } \\
\text { 12.332, }\end{array}$ & $\begin{array}{l}\text { Bird: } \\
\text { no bird } \\
\text { Cod.Or. 2230, 6404, 6446, } \\
\text { 11.650, 12.332, Berlin Ms. }\end{array}$ & $\begin{array}{l}\text { Bird. }^{58} \\
\text { (Me)nori/nari } \\
\text { Cod.Or. 2230, 6405, } \\
\text { 11.650, 12.332, Berlin Ms. }\end{array}$ \\
\hline
\end{tabular}

55 Not illustrated in Add MS 12338.

56 Baruna According to Mulyono 1993: 135.

57 No bird mentioned for this wuku in Cod.Or. 6446. 


\begin{tabular}{|c|c|c|}
\hline $\begin{array}{l}\text { Berlin Ms. or. oct. 4036, } \\
\text { MSS Jav 36, Add MS } \\
12338 \\
\text { Bebek } \\
\text { Cod.Or. 6446, BL Or } \\
15932\end{array}$ & $\begin{array}{l}\text { or. oct. 4036, MSS Jav 36, } \\
\text { Add MS 12338, BL Or } \\
15932\end{array}$ & $\begin{array}{l}\text { or. oct. 4036, Add MS } \\
12338 \\
\text { No bird } \\
\text { BL Or } 15932\end{array}$ \\
\hline $\begin{array}{l}\text { 9. JULUNG WANGI } \\
\text { God: } \\
\text { Sambo/Sambu } \\
\text { Cod.Or. 2230, 6405, 6446, } \\
\text { 11.650, 12.332, Berlin Ms. } \\
\text { or. oct. 4036, MSS Jav 36, } \\
\text { Add MS 12338, BL Or } \\
15932\end{array}$ & $\begin{array}{l}\text { 19. TAMBIR } \\
\text { God: } \\
\text { Mahadewa } \\
\text { Cod.Or. } 2230 \\
\text { Siwah } \\
\text { Cod.Or. 6405, 6446, } \\
\text { 11.650, 12.332, Berlin Ms. } \\
\text { or. oct. 4036, Add MS } \\
\text { 12338, BL Or } 15932\end{array}$ & $\begin{array}{l}\text { 29. Фникит } \\
\text { God: } \\
\text { Basuki } \\
\text { Cod.Or. } 2230 \\
\text { Panyarikan } \\
\text { Cod.Or. } 6405 \\
\text { Pangat } \\
\text { Cod.Or. } 6446 \\
\text { Baruna } \\
\text { Cod.Or. 11.650, Berlin } \\
\text { Ms. or. oct. } 4036 \\
\text { Sakri } \\
\text { Cod.Or } 12.332 \\
\text { Sukri Add MS } 12338 \\
\text { Kaneka } \\
\text { BL Or 15932 }\end{array}$ \\
\hline $\begin{array}{l}\text { Tree: } \\
\text { Ce(m)paka } \\
\text { Cod.Or. 2230, } 11.650 \\
\text { 12.332, Berlin Ms. or. oct. } \\
\text { 4036, MSS Jav 36, Add MS } \\
\text { 12338 } \\
\text { Cendana } \\
\text { Cod.Or. } 6405 \\
\text { Cemara } \\
\text { Cod.Or. 6446, BL Or } 15932\end{array}$ & $\begin{array}{l}\text { Tree: } \\
\text { Tamudhuh } \\
\text { Cod.Or. } 2230 \\
\text { Ingas } \\
\text { Cod.Or. } 6405 \\
\text { Upas } \\
\text { Cod.Or. 6446, 11.650, } \\
\text { 12.332, Berlin Ms. or. oct. } \\
\text { 4036, Add MS 12338, BL } \\
\text { Or 15932 }\end{array}$ & $\begin{array}{l}\text { Tree: } \\
\text { Pandhan (Wangi) } \\
\text { Cod.Or. 2230, 6405, 6446, } \\
\text { 11.650, 12.332, Berlin Ms. } \\
\text { or. oct. 4036, Add MS } \\
\text { 12338, BL Or 15932 }\end{array}$ \\
\hline $\begin{array}{l}\text { Bird: } \\
\text { Kapodhang } \\
\text { Cod.Or. } 2230 \\
\text { Kuthilang/ Kathilang/ } \\
\text { Kulang } \\
\text { Cod.Or. 6405, 6446, 11.650, } \\
\text { 12.332, Berlin Ms. or. oct. } \\
\text { 4036, MSS Jav 36, Add MS } \\
\text { 12338, BL Or 15932 }\end{array}$ & $\begin{array}{l}\text { Bird: } \\
\text { Perenjak } \\
\text { Cod.Or. 2230, 6405, 11.650, } \\
\text { 12.332, Berlin Ms. or. oct. } \\
4036 \\
\text { P(a)rijata } \\
\text { Cod.Or. 6446, Add MS } \\
\text { 12338, BL Or 15932 }\end{array}$ & $\begin{array}{l}\text { Bird: } \\
\text { Ayam Alas/Satawana/ } \\
\text { Sawungwana } \\
\text { Cod.Or. 2230, 6405, 6446, } \\
\text { 11.650, 12.332, Berlin Ms. } \\
\text { or. oct. 4036, Add MS } \\
\text { 12338, BL Or 15932 }\end{array}$ \\
\hline
\end{tabular}




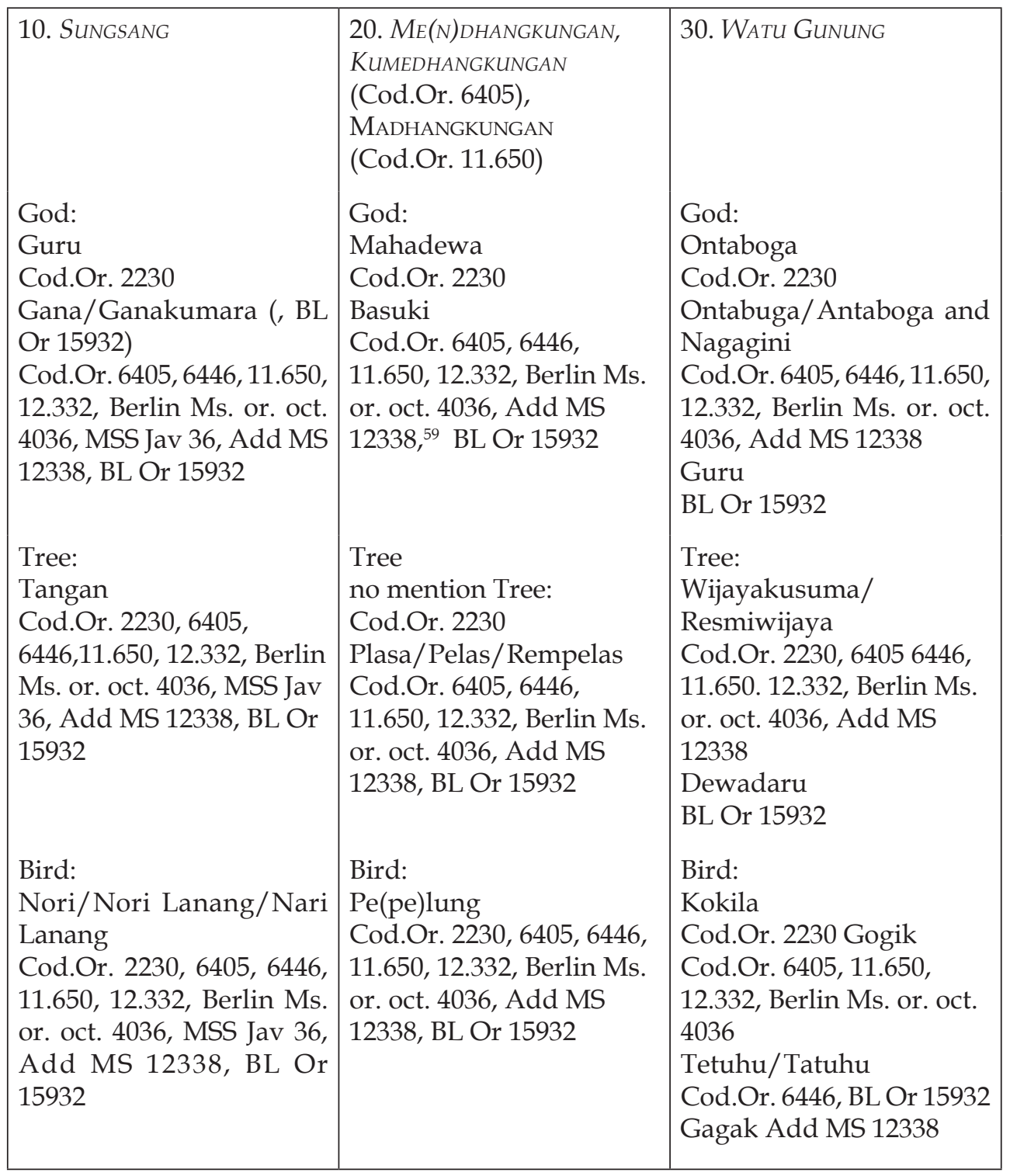

58 In illustration named Onggapati. 